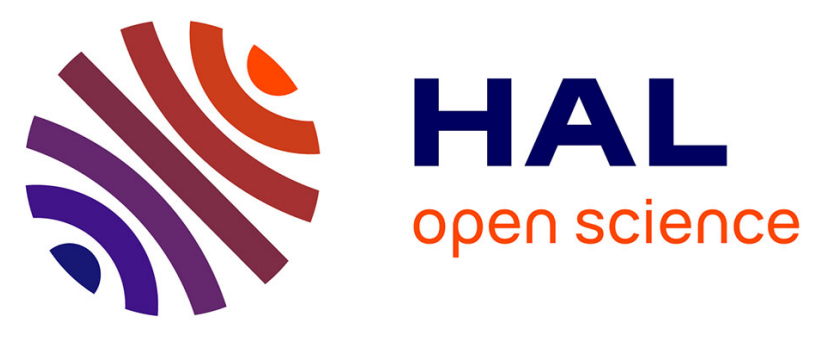

\title{
Photostability of biological systems-Femtosecond dynamics of zinc tetrasulfonated phthalocyanine at cancerous and noncancerous human Breast tissues
}

Halina Abramczyk, Beata Brozek-Pluska, Jakub Surmacki, Marc Tondusson, Eric Freysz

\section{To cite this version:}

Halina Abramczyk, Beata Brozek-Pluska, Jakub Surmacki, Marc Tondusson, Eric Freysz. Photostability of biological systems-Femtosecond dynamics of zinc tetrasulfonated phthalocyanine at cancerous and noncancerous human Breast tissues. Journal of Photochemistry and Photobiology A: Chemistry, 2017, 332, pp.10 - 24. 10.1016/j.jphotochem.2016.08.012 . hal-01382740

\author{
HAL Id: hal-01382740 \\ https://hal.science/hal-01382740
}

Submitted on 19 Oct 2016

HAL is a multi-disciplinary open access archive for the deposit and dissemination of scientific research documents, whether they are published or not. The documents may come from teaching and research institutions in France or abroad, or from public or private research centers.
L'archive ouverte pluridisciplinaire HAL, est destinée au dépôt et à la diffusion de documents scientifiques de niveau recherche, publiés ou non, émanant des établissements d'enseignement et de recherche français ou étrangers, des laboratoires publics ou privés.

\section{(1) (1) $\$$}

Distributed under a Creative Commons Attribution - NonCommercial - NoDerivatives 44.0 


\title{
Photostability of biological systems-Femtosecond dynamics of zinc tetrasulfonated phthalocyanine at cancerous and noncancerous human Breast tissues
}

\author{
Halina Abramczyk ${ }^{\mathrm{a}, *}$, Beata Brozek-Pluska ${ }^{\mathrm{a}}$, Jakub Surmacki ${ }^{\mathrm{a}}$, Marc Tondusson ${ }^{\mathrm{b}}$, \\ Eric Freysz ${ }^{\mathrm{b}}$ \\ ${ }^{a}$ Lodz University of Technology, Institute of Applied Radiation Chemistry, Laboratory of Laser Molecular Spectroscopy, Wroblewskiego 15, 93-590 Lodz, Poland \\ ${ }^{\mathrm{b}}$ Université Bordeaux 1, Laboratoire Ondes et Matière d'Aquitaine (LOMA), UMR-CNRS 5798, 351 Cours de la Libération, 33405 Talence Cedex, France
}

A R T I C L E I N F O

Keywords:

Raman and IR spectroscopy

Breast cancer

Femtosecond pump-probe transient

absorption

Phthalocyanines

Photodynamic therapy

PDT photosensitizers

\begin{abstract}
A B S T R A C T
Zinc tetrasulfonated phthalocyanine $\left(\mathrm{ZnPcS}_{4}\right)$, was studied in aqueous solutions, films and at the biological interfaces of noncancerous and cancerous human breast tissues by using steady state and time resolved spectroscopy methods, including IR, Raman, UV vis, fluorescence and transient absorption femtosecond pump probe spectroscopy. The pump probe transient absorption spectra were recorded on time scales from femtoseconds to nanoseconds providing insight into the molecular mechanisms of energy dissipation and primary events occurring in solution, film, and at the interface of the biological tissues. The nature of the rapid processes and competing relaxation pathways resulting from the initially excited electronic states of $\mathrm{ZnPcS}_{4}$ in aqueous solutions, films and at the biological interfaces of cancerous and noncancerous human breast tissues was studied. The results provide evidence that the sulfonated zinc phthalocyanine dissipates energy through different pathways in the environment of the noncancerous tissue and of the cancerous tissue. A detailed understanding of the paths of energy dissipation will reveal the mechanisms underlying light induced signal transduction and the role of photoreceptors in photostability of living cells. Here, we showed that both the dynamics of the ground state $S_{0}$ recovery and the dynamics of the first excited state $S_{1}$ decay at the interfacial regions of the noncancerous tissue is markedly faster than that in the cancerous tissue, suggesting that the molecular mechanisms responsible for harvesting the light energy in photosensitizers can be used for practical applications in cancer diagnostics. The paper bridges the fundamentals of cancer research with the femtosecond technologies of high temporal resolution for studying dynamics of photosensitizers in noncancerous and cancerous human breast tissues.
\end{abstract}

\section{Introduction}

Biological systems must effectively acclimate to maintain photostability, because there would be no life on earth without it. Thus, molecular biological structures responsible for harvesting solar energy must be resistant to photo induced chemical changes. This feature determines the health disease balance in living creatures. When the photostability protection and reparation mechanisms fail, the processes that convert noncancerous tissue into abnormal tissue are strongly enhanced, leading to disease.

\footnotetext{
* Corresponding author.

E-mail address: abramczy@mitr.p.lodz.pl (H. Abramczyk).
}

Therefore, it is important to characterize the mechanisms governing photostability in living biological systems [1].

To examine photostability new analytical tools, such as Raman imaging and femtosecond spectroscopy, providing high temporal or spatial resolution are required. The high temporal resolution is needed to monitor the primary events occurring upon light excitation, while the high spatial resolution is required to map the localization and distribution of exogenous probes and endogenous cellular components [2,3]

Raman imaging and femtosecond spectroscopy may open new expanses in cancer biology particularly in metabolic and epigenetic modifications of cancer, and bring revolution in cancer detection and treatment. Limited number of papers has been reported on ultrafast dynamics of biologically important molecules such as: proteins and lipids [4 8]. Despite of several model studies that 
have been done so far, no ex vivo ultrafast dynamics of human tissue have been reported yet. High spatial [9 14] and temporal resolution [15 20] allows to detecting a single cancerous cell in vivo and monitor molecular events that occur inside and contribute to cancer development.

In the present study, we used sulfonated zinc phthalocyanine as an exogenous probe to examine the processes occurring at the biological interfaces of human breast tissue. Phthalocyanines play an important role as photosensitizers in conventional and targeted photodynamic therapy (PDT) [15 82] and the mechanisms and dynamics of energy transfer are crucial in this therapy. PDT is a three component therapy involving the photosensitizer (phthalo cyanine), the visible light absorbed through the photosensitizer and molecular oxygen. The photosensitizer, accumulated or retained in the target components of human cells, absorbs light and induces a sequence of photophysical events, such as excited singlet state fluorescence emission, intersystem crossing to a triplet state or electron transfer. The energy dissipation depends on many factors, such as phthalocyanine aggregation or photoinduced reactions at photosensitized interfaces. Aggregation also depends on many factors, such as a central metal, substituent type and solvent composition. Dimers and higher ordered aggregates are generally non fluorescent, as these structures have efficient channels for non radiative relaxation. Thus, aggregation decreases the efficiency of the radiative paths that return the photosensitizer to the ground state via fluorescence or long lived phosphores cence. In contrast, the excited monomeric species of the photosensitizer once upon irradiation emits fluorescence [83].

In this study, we used pump probe femtosecond transient absorption spectroscopy to examine the primary processes occurring in sulfonated zinc phthalocyanine $\left(\mathrm{ZnPcS}_{4}\right)$. However, the early femtosecond and picosecond responses to light irradia tion provide only limited information, as multiple cellular targets make it difficult to distinguish the critical events of PDT that lead to cell death. To understand the molecular basis of cancer cell death through PDT, time resolved spectroscopy methods must be combined with other sensitive techniques that are capable of elucidating the driving forces preceding formation of ROS (reactive oxygen species) from the excited photosensitizer. The sensitive techniques, such Raman and fluorescence imaging, are useful for photosensitizer localization and mapping cellular events during and after photosensitization [2,3]. It has been shown that the degree of photosensitizer aggregation affects localization and distribution $[84,85]$. PDT initiates three types of programmed cell death (PCD): apoptosis, necrosis or autophagy. The exact mecha nism underlying the induction of PCD remains unknown, but it seems that ROS generated from the excited photosensitizer are the driving force underlying these events $[86,87]$.

The detailed mechanisms of photosensitizer localization have been previously discussed [20,85,87]. The initial subcellular localization of each photosensitizer depends on many factors, such as charge, hydrophobicity and plasma protein binding affinity. Based on the charge and hydrophilic or lipophilic properties, the photosensitizer can be localized in the various cytoplasmic membranous structures of certain types of cells or compartments, such as a membrane surfaces, endosomal compartments, organ elles and cytoplasm. Briefly, the charge determines the anionic, cationic, amphiphilic or neutral characteristics of photosensitizers and plays an important role in the cellular uptake and photody namic efficacy of PDT [79]. One of the most important types of interactions between photosensitizers and membrane lipids are electrostatic interactions. The higher efficiency of binding of water soluble tetrasubstituted cationic aluminum phthalocyanine to phospholipid membranes compared to the anionic tetrasulfonated aluminum and zinc phthalocyanine complexes has been proven [80]. This higher efficiency can be easily explained by electrostatic interactions of the photosensitizer with negatively charged lipids contained in the membrane [81]. The hydrophilic or lipophilic properties of the photosensitizers are related to their structure, which regulates aggregation and the efficiency of singlet oxygen production [84]. Among the hydrophilic photosensitizers, anionic derivatives with sulfo substituents (Fig. 1), such as $\mathrm{ZnPcS}_{4}$ or $\mathrm{AlPcS}_{4}$ are one the best photosensitizers. It has been reported that the high lipophilicity correlates with high cancer affinity of the photosensitizer, while high hydrofility correlates with high phototoxicity of the photosensitizer [82]. Moreover, it has been shown that anionic phthalocyanines have higher selectivity in binding process than cationic phthalocyanines and some cationic compounds can be used in targeted therapy for destroying specific subcellular organelles such as mitochondria [88 92]. Although the cellular mechanisms of the mitochondrial pathway involved in cancer cell elimination through photodynamic therapy remain largely unclear, several studies on the mechanism of PDT induced apoptosis have suggested the involvement of pro and anti apoptotic proteins, e.g., Bcl 2, Bax, Bcl XL, and most importantly p53 $[86,87,93]$. The tumor suppressor protein p53 is critically involved in defense against genome alterations resulting from DNA damage. Although the precise role of $\mathrm{p} 53$ remains elusive, it has recently been well documented that p53 confers a crucial barrier for cancer progression, as p53 inactivation during tumorigenesis occurs with high frequency via multiple mechanisms [86,87].

The significant progress made since the mid 1990s in cancer detection and PDT therapy correlates with the development of selective photosensitizers localized to specific sites of cells and tissues such as plasma membrane, nuclei, mitochondria, and lysosomes [94,95]. The high specificity of these new photo sensitizers can be enhanced by using conjugated antibodies that
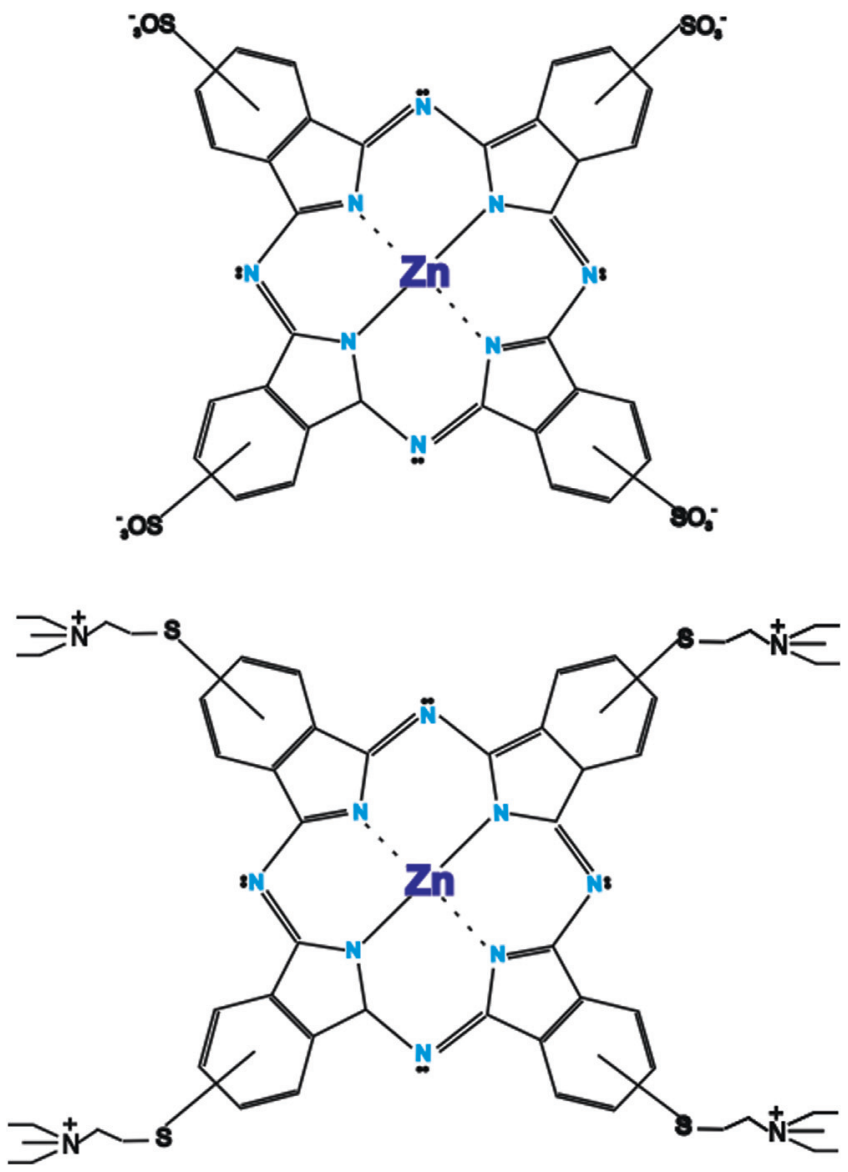

Fig. 1. Anionic and cationic zinc photosensitizers. 
recognise and bind to cancer cells [96 98]. The targeting approach combining nanoparticles with laser spectroscopy and Raman imaging can potentially revolutionize cancer diagnosis and therapy [11,95]. In the present study, we focused on the biological interfaces after suspension and adsorption of photosensitizer in a biological medium of noncancerous and cancerous human breast tissues. Tetrasulfonated zinc phthalocyanine (Fig. 2) was selected as a hydrophilic and anionic photosensitizer to identify the primary processes occurring upon excitation of the chromophore. We examined the vibrational properties and dynamics of sulfonated zinc phthalocyanine at the biological interface of the human breast tissues in a time window ranging from femto seconds to nanoseconds. The results were compared with the dynamics of the photosensitizer in the film on the glass support and in aqueous solutions. Understanding mechanisms of energy dissipation at the biological interface is a key challenge of photochemistry of photosensitizers in vivo. Although photochem ical properties of photosensitizers in liquid solutions has been well documented [49 58]. We have shown [20] that bulk solution properties of photosensitizers at biological interfaces cannot be translated to the solid phase. Therefore, the photochemistry of photosensitizers must be significantly revised when considering biological interfaces. A limited number of papers have reported on the dynamics of the primary events upon light excitation in thin phthalocyanines films $[12,15,60,65,73,75,80,99105]$.

Although the primary PDT mechanism has been associated with the selective accumulation of photosensitizers in cancer tissue, it remains completely unclear whether the photochemical pathways of energy dissipation upon light excitation are the same in the noncancerous and cancerous tissues. The answer to this long standing question, representing a key challenge in clinical applications, can be elucidated using the time resolved pump probe method to monitor pathways of photodynamic reactions in regions of noncancerous and cancerous cells.
The aim of the present study was to elucidate the processes responsible for the ultrafast dynamics of $\mathrm{ZnPcS}_{4}$ at biological interfaces of the human noncancerous and cancerous tissues occurring on a time scale from femtoseconds to nanoseconds by using the pump probe transient absorption spectroscopy. The ultrafast dynamics was induced through femtosecond laser pulses centered at 674 and $633 \mathrm{~nm}$ corresponding to the absorption maxima of the $\mathrm{Q}$ band of the monomer and dimer, respectively.

\section{Experimental section}

\subsection{Phthalocyanine}

Zinc phthalocyanine tetrasulfonic acid, tetrasodium salt $\left(\mathrm{ZnPcS}_{4}\right)$ was prepared using a method similar to that of Griffiths et al. [106]. More details about the synthesis can be found elsewhere [20]. Scheme 1 illustrates the method used for the synthesis of $\mathrm{ZnPcS}_{4}$.

This method generated a single regioisomer, presented in Fig. 3. Fig. 3 shows the structure of the metal phthalocyanine, zinc (II) phthalocyanine $3,4^{\prime}, 4^{\prime \prime}, 4^{\prime \prime \prime}$ tetrasulfonic anion.

\subsection{Steady state UV vis absorption measurements}

UV vis absorption electronic spectra were recorded with a Varian Cary 5E spectrophotometer using 2 and $0.10 \pm 0.005 \mathrm{~mm}$ detachable quartz cells (Hellma). The spectra were recorded at $293 \mathrm{~K}$ for the aqueous solutions at concentration of $\mathrm{c}=10{ }^{3} \mathrm{M}$, as well as $\mathrm{ZnPcS}_{4}$ films on $\mathrm{BaF}_{2}$ supports and the thin sections of $16 \mu \mathrm{m}$ of cancerous and noncancerous human breast tissue samples stained with $\mathrm{ZnPcS}_{4}$.

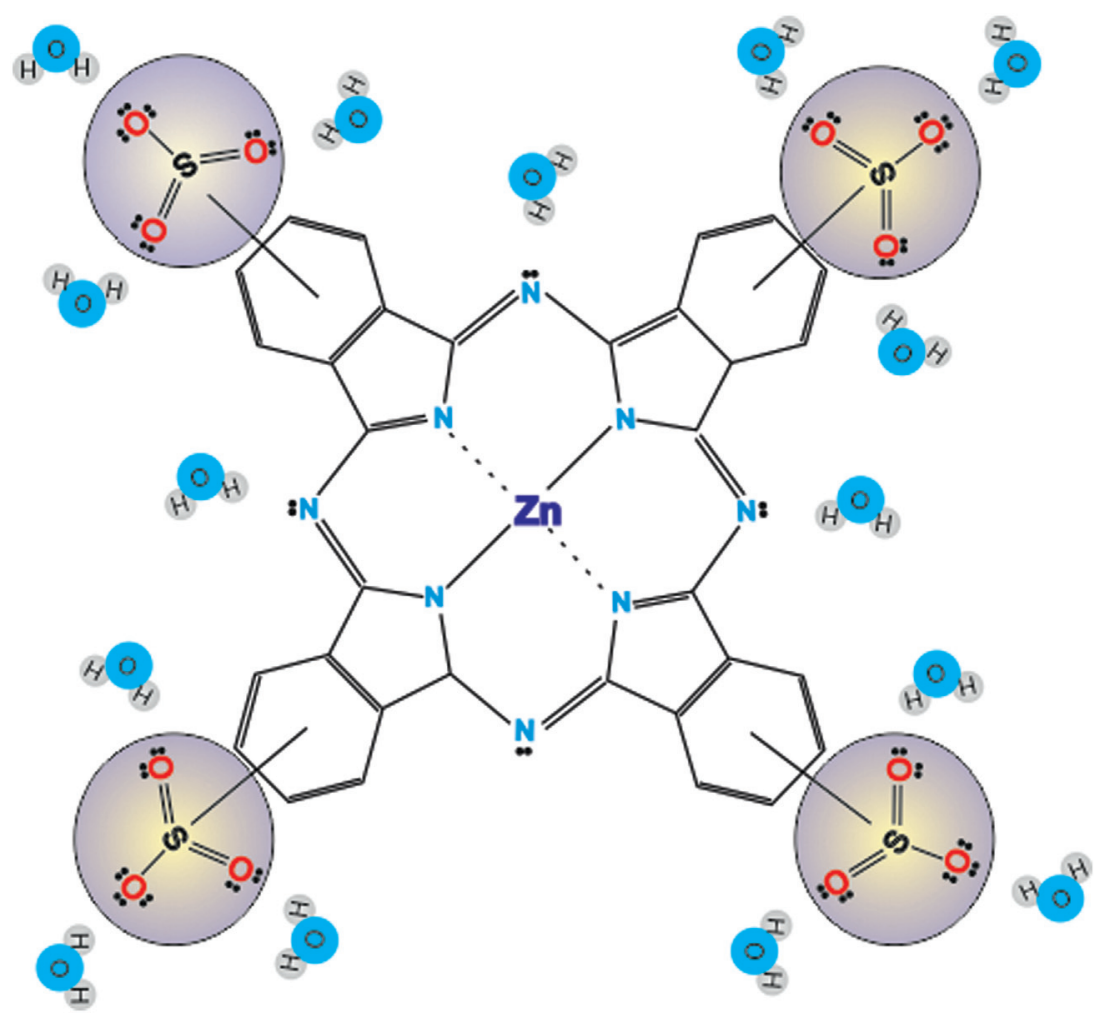

Fig. 2. Hydrophilic and anionic character of $\mathrm{ZnPcS}_{4}$. 


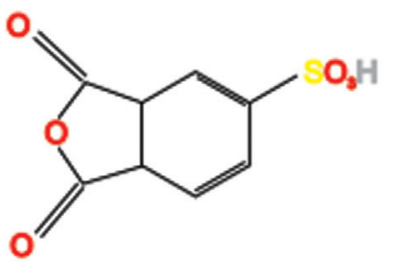

urea ammonium molibdate zinc chloride boric acid anhydrous zinc chioride sulfolane, $2000 \mathrm{C}$

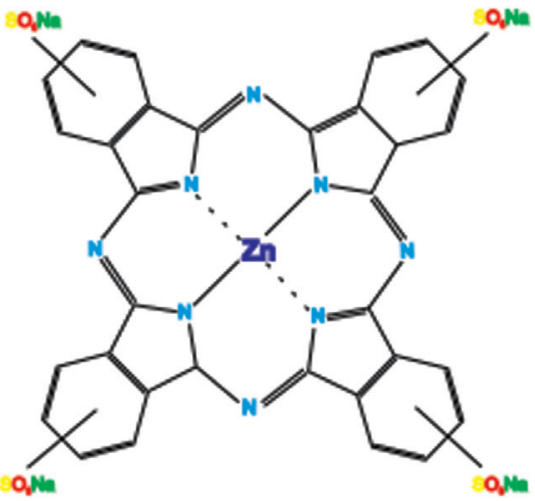

Scheme 1. Method used for the synthesis of $\mathrm{ZnPcS}_{4}$ via the condensation of the sulfonated precursors in the presence of urea, the selected metal salt and a catalyst

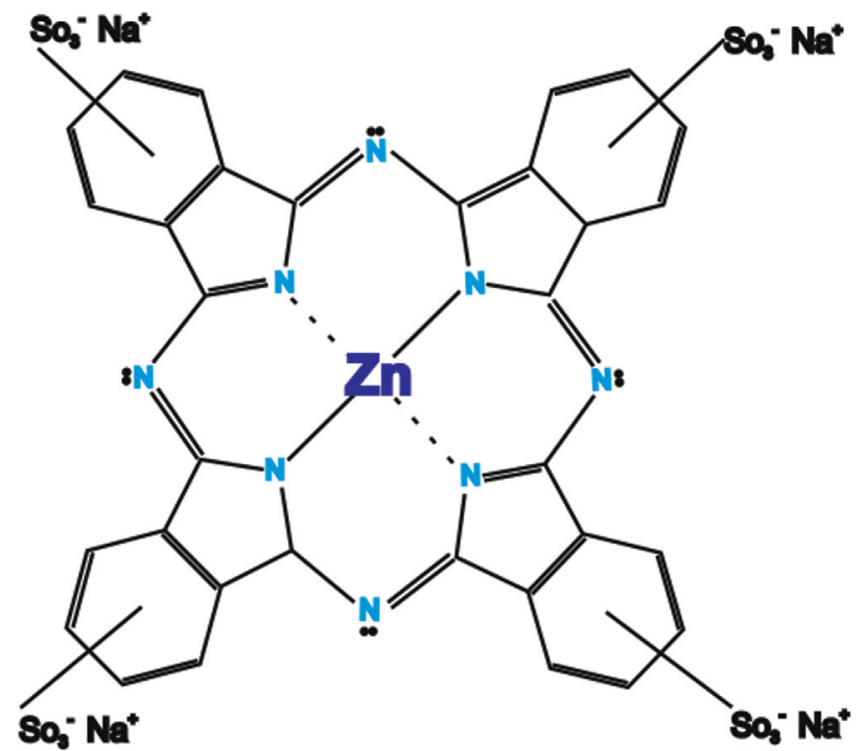

Fig. 3. Structure of the metal phthalocyanine, zinc(II)phthalocyanine- $3,4^{\prime}, 4^{\prime \prime}, 4^{\prime \prime \prime}-$ tetrasulfonic anion.

\subsection{Pump probe transient absorption spectroscopy}

The source of femtosecond pulses was a mode locked titanium sapphire femtosecond laser (MIRA, Coherent, $800 \mathrm{~nm}, 76 \mathrm{MHz}, 9 \mathrm{~nJ}$, $<200 \mathrm{fs}$ ) pumped with iode pumped solid state laser (VERDI V5, Coherent, $532 \mathrm{~nm}$ ). The fundamental beam was amplified with Ti: Sapphire regenerative amplifier (Coherent Legend USP, $800 \mathrm{~nm}$, $1 \mathrm{kHz}, 3 \mathrm{~mJ}, 50 \mathrm{fs})$. The regenerative amplifier was pumped with diode pumped Nd:YLF laser (JADE, Thales Laser, $527 \mathrm{~nm}, 1 \mathrm{kHz}$, $20 \mathrm{~mJ},<200 \mathrm{~ns}$ ). The pulse was split in two and further amplified to a dual single pass amplifier (Coherent Elite Duo, $800 \mathrm{~nm}, 1 \mathrm{kHz}$, $2 \times 4.5 \mathrm{~mJ}, 50 \mathrm{fs}$ ). This amplifier was pumped through high power $\mathrm{Nd}$ :YLF laser (Evolution, Coherent, $527 \mathrm{~nm}, 50 \mathrm{~mJ},<200 \mathrm{~ns}$ ). The output of the laser system was split and two $1 \mathrm{~mJ}$ laser pulses were used to pump two optical parametric amplifiers (OPA, model TOPAS from Light Conversion). These OPA, combined through frequency conversion modules, generated femtosecond pulses tunable in the 300 and $2600 \mathrm{~nm}$ ranges. More details about the femtosecond laser setup can be found in Ref. [20].

\subsection{Patients and samples}

We examined human ductal and lobular carcinoma (in situ and infiltrating) and various benign changes, including benign dysplastic and neoplastic lesions [107,108]. Raman spectroscopy and Raman imaging have been previously used to analyze breast cancer specimens [109 111]. The breast tissue samples were obtained during a surgical operation. The research did not affect the course of the operation or treatment of the patients. All procedures were conducted using the protocol approved through the institutional Bioethical Committee at the Medical University of Lodz, Poland (RNN/30/11/KE). The detailed description of the sample preparation procedure can be found in Ref. [20].

\subsection{Infrared spectroscopy}

IR spectra were recorded using a Specord M 80, Germany. Specord M80 is a double beam spectrometer for the measurement of lead $4000200 \mathrm{~cm}^{1}(2.550 \mu \mathrm{m})$ with an accuracy ranging from $+/ 0.8 \mathrm{~cm}^{1}$ to $+/ 0.3 \mathrm{~cm}{ }^{1}$, depending on the spectral a)

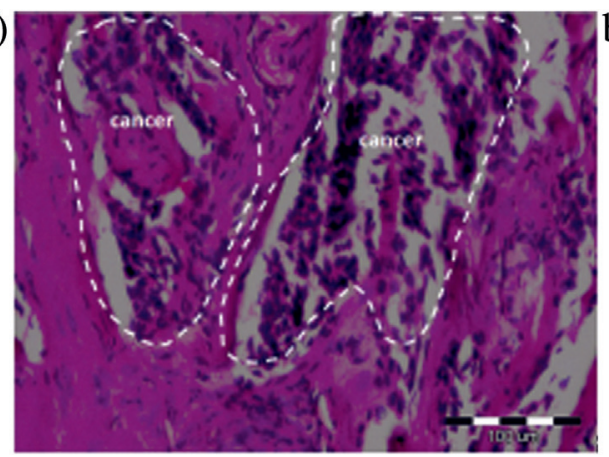

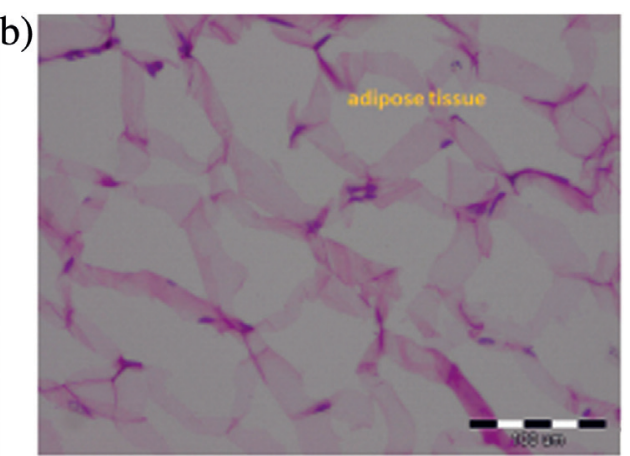

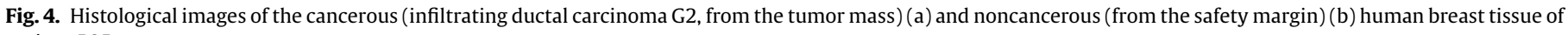
patient P95. 
range. The spectra were scanned with a $4 \mathrm{~cm}^{1}$ step and recorded in a $8004000 \mathrm{~cm}^{1}$ range at $293 \mathrm{~K}$.

\section{Results and discussion}

To learn about the properties of the photosensitizers at the interface of cancerous and noncancerous tissues and the corre sponding biochemical components of the tissue that form biological environment for the photosensitizers we employed a broad range of spectroscopic methods.

In this section, the results for the photosensitizer $\left(\mathrm{ZnPcS}_{4}\right)$ at the interface of the noncancerous and cancerous human breast tissues using various methods, such as Raman, IR, and UV vis steady state spectroscopy methods and time resolved transient electronic absorption through the pump probe femtosecond spectroscopy will be presented.

Fig. 4 presents the histological images of the tumor mass (cancerous tissue) and tissue from the safety margin (noncancer ous tissue) of the same patient P95. The samples obtained from this patient have also been used to record the Raman and IR spectra to analyze the biochemical composition of cancerous and noncan cerous human breast samples.

The histological images were obtained by staining with hematoxylin and eosin (H\&E). $\mathrm{H} \& \mathrm{E}$ staining facilitates the assignment of various structures in tissues and single cells [107]. Hematoxylin stains all basophilic components blue, particularly the nucleus, containing DNA and RNA, and the rough endoplasmic reticulum as a result of the coordinated bonding
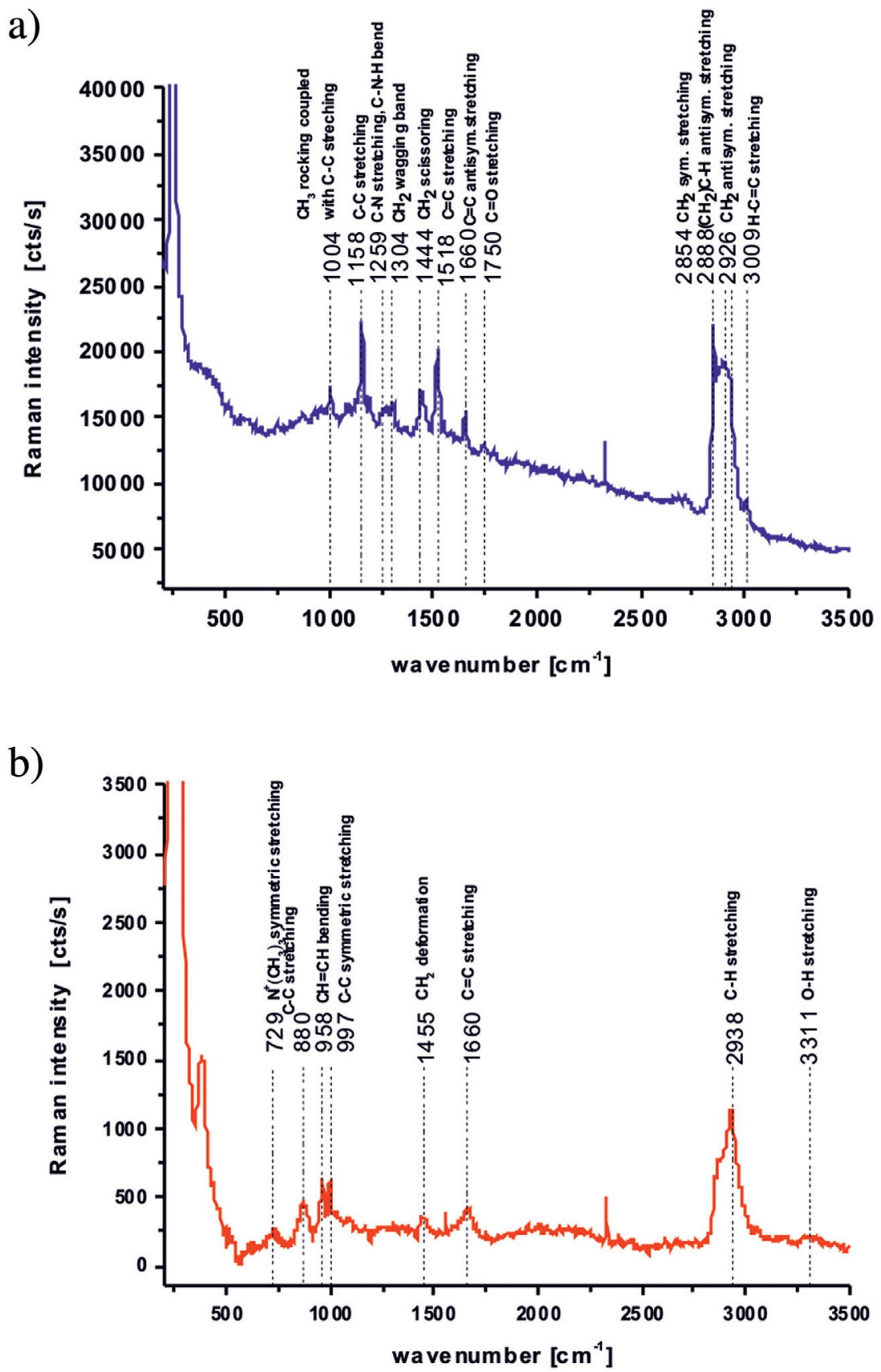

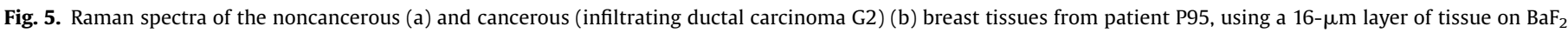
window. 
between aluminum and the phosphor atoms in DNA and RNA [112]. Eosin stains cytoplasm, connective tissue and collagen fibers (eosinophilic substances) red due to the ionic bonds between the anionic dye and cationic plasma proteins.

To understand the details of the histological images presented in Fig. 4, we will discuss the basic information on the morphology of the human breast. The human breast consists of 610 major duct systems. Each system contains numerous lobules, which terminate ducts. Adipose tissue and supporting stroma surrounds these ducts and lobules. The disease develops in the epithelial cells of the ducts (ductal carcinoma) and lobules (lobular carcinoma). These tissues contain no blood vessels; thus, nourishment is provided via the diffusion of substances from the connective tissue surrounding the epithelial structures [113]. These structures can be easily seen in the histological H\&E images presented in Fig. 4. The epithelial cells are surrounded by the stroma, which predominantly, but not exclusively, comprises connective tissue (type I collagen) (Fig. 4a) and adipose tissue (Fig. 4b). The surface of the cancerous tissue is hydrophilic [114], and the level of various proteins is markedly elevated during disease development. In contrast, the noncancer ous breast tissue consists of fatty tissue and is hydrophobic, as this tissue primarily comprises glycerol monooleate [114].

\subsection{Steady state Raman scattering}

To obtain insight into the vibrational properties of the tissue constituents at biological interfaces at the molecular level and characterize the nature of these interactions, we analyzed the Raman vibrational features in the noncancerous and the cancerous tissues. Fig. 5 shows the typical Raman spectra of the noncancerous and cancerous human breast tissues of patient P95, with the tentative assignments of major vibrational bands.

The results show that the Raman spectra contain multiple contributions from proteins, lipids, and nucleic acids, with contributions from individual RNA and DNA bases (adenine, thymine, guanine, cytosine, and uracil) and the sugar phosphate backbone of DNA. A detailed inspection of Fig. 5a and b revealed that the Raman spectra are characteristic of adipose rich regions, phospholipid rich regions (Table 1 ), disordered collagen regions (Table 2 ), collagen poor regions (Table 3 ).

The results shown in Fig. 5 highlight differences between the Raman spectra of the noncancerous breast tissue from the safety margin (Fig. 5a) and the cancerous breast tissue from the tumor mass (Fig. 5b). Comparing the spectra in Fig. 5a and b one can notice that the noncancerous human breast tissue contains Raman peaks at 2854, 2888, and $2926 \mathrm{~cm}^{1}$ typical for glycerol mono oleate derivatives [12 14,120,121]. These peaks are not observed in the Raman spectrum of the cancerous tissue for which a protein peak at $2938 \mathrm{~cm}^{1}$ is characteristic. One can also see from Fig. 5 that the strong signals at $1158 \mathrm{~cm}^{1}$ and $1518 \mathrm{~cm}{ }^{1}$ in the Raman spectrum of the noncancerous tissue are clearly visible. These peaks originate from carotenoids, which are not observed in the cancerous human breast tissue. It indicates that the noncancerous human breast tissue contains a higher amount of glycerol monooleate derivatives typical for adipose tissue, which act as reservoir of carotenoids and fatty acids. The third most important difference between the noncancerous and cancerous human breast tissues is observed in the Raman spectra of the Amide I. The maximum peak position of Amide I has been shifted from $1660 \mathrm{~cm}^{1}$ in the cancerous tissue to $1654 \mathrm{~cm}^{1}$ in noncancerous tissue. This effect must be associated with the distinct biological environment, potentially related to the disordered and alpha helical protein structures, respectively. Many distinctions can also be observed in the region of $28003000 \mathrm{~cm}^{1}$ typical for lipid/ protein vibrations, where the contribution from the monounsatu rated fatty acids, common constituents of triglycerides of the adipose tissue, dominates the Raman spectrum of the noncancer ous tissue in contrast to the Raman spectra of the cancerous tissue. We have shown that the Raman spectra of the cancerous tissue demonstrate a protein like profile [12 14,118,121 123]. This finding is consistent with the knowledge that in contrast to noncancerous cells, abnormal cells divide in an uncontrolled process of cell growth and synthesize large amounts of proteins.

Tables 13 show the strongest Raman signals for the noncancerous and the cancerous tissues and the tentative assignments.

Table 1

Characteristic Raman peaks for noncancerous and cancerous breast tissues of adipose-rich regions, phospholipid-rich regions.

\begin{tabular}{|c|c|}
\hline Wavenumber/cm ${ }^{1}$ & Tentative assignments \\
\hline 729 & Nucleic Acids, Phospholipid (choline) [112-114] \\
\hline 1004 & $\begin{array}{l}\text { Carotenoids/Phenylalanine [115] } \\
\text { (C-C) str. }\end{array}$ \\
\hline 1064 & $\begin{array}{l}\text { Lipids/Collagen }[112,113] \\
\text { (C-C) str. }\end{array}$ \\
\hline 1158 & Carotenoids (C-C str.)/Proteins (C-C/C-N str.) [112-116] \\
\hline $1220-1285$ & Nucleic Acids (T, A)/Proteins (Amide III), Lipid, phospholipid $\quad \mathrm{C}-\mathrm{H}$ bend $[112,113]$ \\
\hline 1304 & $\begin{array}{l}\text { Lipids, phospholipids }[112] \\
\left(\mathrm{C}-\mathrm{H}_{2}\right) \text { tw }\end{array}$ \\
\hline 1444 & $\begin{array}{l}\text { Lipids/Proteins }[115,117] \\
\text { (C-H) wag. }\end{array}$ \\
\hline 1528 & $\begin{array}{l}\text { Carotenoids }[116] \\
(\text { C C) str. }\end{array}$ \\
\hline $1655-1680$ & $\begin{array}{l}\text { Proteins Amide I/Unsaturated fatty acids [112,117] } \\
\alpha \text { helix, (C-N) str., (C-H) def./(C C }) \text { str. [112,117] }\end{array}$ \\
\hline 2854 & $\begin{array}{l}\text { Fatty acids, triglicerides }[113] \\
\left(\mathrm{C}-\mathrm{H}_{2}\right) \text { sym. str. }\end{array}$ \\
\hline 2888 & $\begin{array}{l}\text { Lipids [117] } \\
\left(\mathrm{C}-\mathrm{H}_{2}\right) \text { antisym. str. }\end{array}$ \\
\hline 2926 & $\begin{array}{l}\text { Proteins/Lipids }[113,117] \\
\left(\mathrm{CH}_{3}\right) \text { antisym. str. }\end{array}$ \\
\hline 2935 & $\begin{array}{l}\text { Proteins/Lipids [117] } \\
\left(\mathrm{CH}_{3}\right) \text { sym. str. }\end{array}$ \\
\hline 3008 & $\begin{array}{l}\text { Lipids }[112,117] \\
(\mathrm{C}-\mathrm{H}) \text { str. }\end{array}$ \\
\hline
\end{tabular}

Abbreviations: (bend.) bending, (wag.) wagging, (def.) deformation, (tw.) twist, (sym.) symmetric, (antisym.) antisymmetric, and (str.) stretch. 
Table 2

Characteristic Raman peaks for noncancerous and cancerous breast tissues of disordered collagen regions.

\begin{tabular}{|c|c|}
\hline Wavenumber/cm ${ }^{1}$ & Tentative assignments \\
\hline 814 & $\begin{array}{l}\text { Collagen/RNA [112,117] } \\
(\mathrm{C}-\mathrm{C}) /(\mathrm{O}-\mathrm{P}-\mathrm{O}) \text { str. }\end{array}$ \\
\hline 852 & Collagen, Tyrosine $[121,113]$ \\
\hline 880 & $\begin{array}{l}\text { Lipids/Carbohydrates/Collagen [112] } \\
\left(\mathrm{C}-\mathrm{C}-\mathrm{N}^{+}\right),(\mathrm{C}-\mathrm{O}-\mathrm{C}) \text { ring, }(\mathrm{C}-\mathrm{C})\end{array}$ \\
\hline 935 & $\begin{array}{l}\text { Hydroxyproline/Collagen backbone }[113,114] \\
\text { (C-C) }\end{array}$ \\
\hline 1018 & $\begin{array}{l}\text { Collagen }[113] \\
(\mathrm{C}-\mathrm{N})\end{array}$ \\
\hline 1031 & $\begin{array}{l}\text { Collagen }[113] \\
(C-C)\end{array}$ \\
\hline 1125 & Carbohydrates (C-O)/Proteins (C-N str.) [112,113] \\
\hline $1220-1285$ & Nucleic Acids (T, A)/Proteins (Amide III)/Lipid, phospholipid ( $\mathrm{C}-\mathrm{H}$ bend.) $[112,113]$ \\
\hline 1444 & $\begin{array}{l}\text { Lipids/Proteins }[115,117] \\
\text { (C-H) wag. }\end{array}$ \\
\hline $1655-1680$ & $\begin{array}{l}\text { Proteins Amide I/Unsaturated fatty acids [112,117] } \\
\alpha \text { helix, (C-N) str., (C-H) def./C C str. }\end{array}$ \\
\hline 3311 & $\begin{array}{l}\text { Water }[113] \\
(\mathrm{OH}) \text { str. }\end{array}$ \\
\hline 3060 & $\begin{array}{l}\text { Nucleic acids/Proteins [117] } \\
\text { (C-H) aromatic }\end{array}$ \\
\hline
\end{tabular}

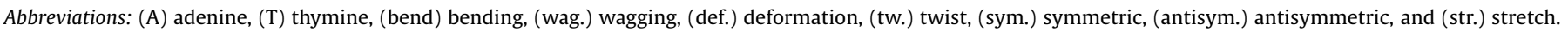

Table 3

Characteristic Raman peaks for noncancerous and cancerous breast tissues of collagen-poor regions.

\begin{tabular}{|c|c|}
\hline Wavenumber/cm ${ }^{1}$ & Tentative assignments \\
\hline 838 & $\begin{array}{l}\text { Nucleic acids, Proteins [113] } \\
\text { (O-P-O) antisym. str./ring br. Tyrosine }\end{array}$ \\
\hline 1076 & $\begin{array}{l}\text { Proteins/Lipids [117] } \\
\text { (C-N) str./chain (C-C) str. }\end{array}$ \\
\hline 1127 & $\begin{array}{l}\text { Proteins/Lipids/Carbohydrates [117] } \\
\text { (C-N) str./chain (C-C) str./(C-O) str. }\end{array}$ \\
\hline 1304 & $\begin{array}{l}\text { Lipids, phospholipids }[112] \\
\left(\mathrm{C}-\mathrm{H}_{2}\right) \text { tw. }\end{array}$ \\
\hline 1444 & $\begin{array}{l}\text { Lipids/Proteins }[115,117] \\
\text { (C-H) wag. }\end{array}$ \\
\hline $1655-1680$ & $\begin{array}{l}\text { Proteins Amide I/Unsaturated fatty acids [112,117] } \\
\alpha \text { helix, (C-N) str., (C-H) def./C C str. }\end{array}$ \\
\hline
\end{tabular}

Abbreviations: (wag.) wagging, (tw.) twist, (sym.) symmetric, (antisym.) antisymmetric, and (str.) stretch.

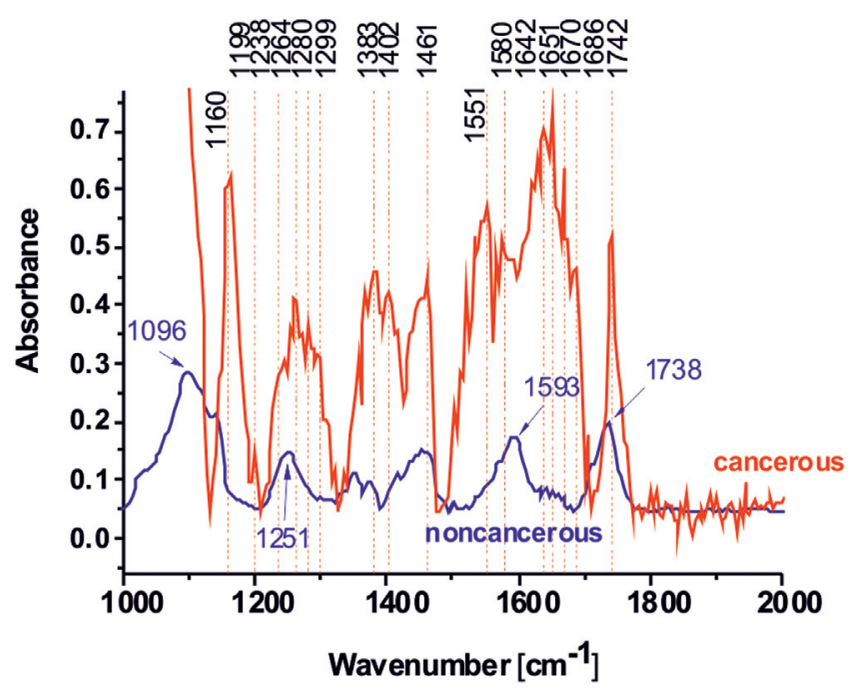

Fig. 6. Comparison between the IR spectra of the cancerous (infiltrating ductal carcinoma G2) and noncancerous breast tissues of patient P95 at 0\% humidity.

\subsection{Steady state IR absorption}

To obtain complementary information concerning the vibra tional properties of the noncancerous and cancerous tissues, it would be interesting to compare the Raman spectra with IR spectra. Fig. 6 shows the typical IR spectra for the cancerous breast tissue of the same patient (P95) shown in Fig. 5. The results show that the absorbance of various vibrations differs markedly, particularly in the region of Amide I and fatty acids (1642, 1651, 1670 , and $1686 \mathrm{~cm}^{1}$ ).

Table 4 presents the tentative assignments of major vibrational bands of IR spectra for the cancerous (infiltrating ductal carcinoma G2) and the noncancerous breast tissues of patient P95.

A detailed analysis of the IR and Raman spectra of the human breast tissue is beyond the scope of this paper, and additional report directly related to this issue will be prepared in future studies.

\subsection{Steady state electronic absorption measurements}

To obtain information concerning the electronic features of the photosensitizer in the noncancerous and cancerous tissues we have compared the electronic spectra of $\mathrm{ZnPcS}_{4}$ in various environments.

Fig. 7a shows the steady state electronic absorption spectra of $\mathrm{ZnPcS}_{4}$ in water, in the film on a glass support, and at the biological interface of noncancerous and cancerous human breast tissues. The results show that sulfonated zinc phthalocyanine absorbs in the $600680 \mathrm{~nm}$ region, known as the Q band, corresponding to a $\pi \pi^{*}$ ring transition [124]. Another intensity band, due to electronic transitions, consistent with the B (or Soret band), is observed at $335 \mathrm{~nm}$. A maximum at around $679 \mathrm{~nm}$ (Fig. 7a) has been attributed to the $\mathrm{Q}$ band $\left(\left(\mathrm{a}_{2 \mathrm{u}}\right) \rightarrow\left(\mathrm{e}_{\mathrm{g}}\right)\right.$ transition $)$ of $\mathrm{ZnPcS}_{4}$ monomers in aqueous solution. Recently we have shown [5] that the absorption band shape and the intensity change in the concentration range of $10^{6} 10^{2} \mathrm{M}$, indicating that aggregation of $\mathrm{ZnPcS}_{4}$ molecules in aqueous solution occurs. The band at $633 \mathrm{~nm}$ in Fig. 7a has been assigned to a dimer or higher aggregates. As for most metallophthalocyanines, the $\mathrm{ZnPcS}_{4}$ dimers with a cofacial dimer geometry [125 127] show absorption that is blue shifted relative to the monomer absorption band at $679 \mathrm{~nm}$. The face to face aggregation, reflecting the extensive interaction between the 
Table 4

The tentative assignments of major vibrational bands of IR spectra for the cancerous (infiltrating ductal carcinoma G2) and noncancerous breast tissues of patient P95.

\begin{tabular}{|c|c|}
\hline Wavenumber/cm ${ }^{1}$ & Tentative assignments \\
\hline 1096 & Phospholipids, O-P-O sym. str. [113] \\
\hline 1160 & Carotenoids C - C str. [115] \\
\hline 1199 & $\mathrm{C}-\mathrm{C}_{6} \mathrm{H}_{5}$ Phe, $\operatorname{Trp}[112]$ \\
\hline 1238 & Phospholipid, O-P-O asym. str. [113] \\
\hline $1220-1285$ & Nucleic Acids (T, A)/Proteins (Amide III), Lipid, phospholipid ( $\mathrm{C}-\mathrm{H}$ bend.) $[112,113]$ \\
\hline \multirow[t]{2}{*}{1299} & Lipids, phospholipids [112] \\
\hline & $\mathrm{CH}_{2}$ tw. \\
\hline 1383 & Lipids $\mathrm{CH}_{3}$ sym. bend., lipids [113] \\
\hline \multirow[t]{2}{*}{1402} & Amine $\mathrm{C}-\mathrm{N}$ str. [113] \\
\hline & Lipids $\mathrm{N}+\left(\mathrm{CH}_{3}\right)_{3}$ sym. bend. \\
\hline 1461 & Phospholipids $\left(\mathrm{CH}_{2}\right)$ scissoring [113] \\
\hline 1551 & Amide II, proteins [113] \\
\hline 1580 & Nucleic acids [112,113] \\
\hline 1642 & Water $\mathrm{OH}$ bend [113] \\
\hline \multirow[t]{3}{*}{$1655-1680$} & Proteins Amide I $[112,117]$ \\
\hline & $\alpha$ helix, $\mathrm{C}-\mathrm{N}$ stretch, $\mathrm{CH}$ deformation, Unsaturated fatty acids \\
\hline & C C str. $[112,117]$ \\
\hline 1738 & Lipids C O str. $[113,115,117,119]$ \\
\hline 1742 & Lipids C O str. $[113,115,117,119]$ \\
\hline
\end{tabular}

Abbreviations: (bend) bending, (wag) wagging, (def.) deformation, (tw) twist, (sym) symmetric, (antisym) antisymmetric, and (str) stretch.

$\pi$ systems of adjacent rings [125], is stabilized through hydrogen bonding in tetrasulfonated $\mathrm{ZnPcS}_{4}$ [127].

In contrast to the solutions, the absorption spectra at the biological interface of the tissues and in the film presented in Fig. 7a exhibit broad, structureless bands characteristic for the absorption of monomers, dimers, and higher order aggregates. Assuming the thickness of the $\mathrm{ZnPcS}_{4}$ layer for about $100 \mu \mathrm{m}$ we have estimated the concentration of the photosensitizer in the tissues to be around $10^{2} \mathrm{M}$.

For comparison, in Fig. $7 \mathrm{~b}$ we showed the steady state absorption spectra of $\mathrm{AlPcS}_{4}$ in water solution, in a film, and at the biological interface of noncancerous and cancerous human breast tissues. AlPcS 4 does not to aggregate in either aqueous or organic solvents [128]. The sharp band at around $679 \mathrm{~nm}$ has been assigned to monomeric species, and the weak band at $602 \mathrm{~nm}$ to the vibronic band.

Excited state dynamics of ZnPcS4 at biological interfaces of the human cancerous and noncancerous breast tissues, films and in aqueous solutions. SO $\rightarrow \mathrm{S} 1$ transition ( $\mathrm{Q}$ band transition).

Upon absorbing a photon, a molecule is promoted to higher energy states and very quickly relaxes back to ground state through radiative or non radiative (heat) pathways. All these pathways can be depicted in the Jablonski diagram [129].

When radiative path is chosen, profound chemical rearrange ments occur leading to dangerous photoreactions in living cells, thereby reducing photostability protection. In contrast in fast non radiative processes no profound chemical or structural rearrange ments can occur [1]. This pathway of ultrafast nonradiative decay can be observed in many biological systems $[1,130,131]$.

To elucidate additional electronic dynamics from the signals of the transient absorption $\Delta A(t)$, we need to understand the details of the electronic transitions in zinc phthalocyanines, which are induced and probed through the laser pulses in the pump probe experiments.

To monitor dynamics upon phthalocyanine excitation the time evolution of transient absorption signals were monitored with a time resolution of $50 \mathrm{fs}$.

To obtain insight into the mechanisms of energy dissipation, we monitored the dynamics of $\mathrm{ZnPcS}_{4}$ at the interfacial region of human breast tissues upon excitation of the $S_{0} \rightarrow S_{1}$ transition in the $\mathrm{Q}$ band at $674 \mathrm{~nm}$ (maximum absorption of monomer) and at $633 \mathrm{~nm}$ (maximum absorption of dimer) and probing at different wavelengths $(570 \mathrm{~nm}, 633 \mathrm{~nm}, 674 \mathrm{~nm})$ corresponding to the excited state, dimer, and monomer absorption spectra, respective ly.

Fig. 8 shows the transient absorption signals $\Delta A(t)$ of $\mathrm{ZnPcS}_{4}$ at the interface of the cancerous tissue, noncancerous tissue, in the film, and in solution as a function of the time delay in the pump probe experiments when pumped with $674 \mathrm{~nm}$ and probed with $674 \mathrm{~nm}$. The results are presented in the full time window up to 10 ps (Fig. 8a) and in the narrower windows up to 100 ps (Fig. 8b) and up to 1 ns (Fig. $8 \mathrm{c}$ ).

The results shown in Fig. 8 indicate that directly upon excitation at $674 \mathrm{~nm}$, a negative transient absorption $\Delta A(t)$ signal at $674 \mathrm{~nm}$ was recorded. The negative signal was assigned to the bleaching of the ground state due to the $\operatorname{HOMO}\left(\mathrm{a}_{1 \mathrm{u}}\right) \rightarrow \operatorname{LUMO}\left(\mathrm{e}_{\mathrm{g}}\right)$ transition in the $\mathrm{Q}$ band for monomer $\mathrm{ZnPcS}_{4}$ molecules. The bleaching is instantaneous and limited by the laser pulse width.

The recovery at $674 \mathrm{~nm}$ was three exponential and fitted with time constants of $1.7 \pm 0.4 \mathrm{ps}, 24.4 \pm 3.1 \mathrm{ps}$ and $59.3 \pm 4.4 \mathrm{ps}$ for the noncancerous tissue and $8.3 \pm 1.2 \mathrm{ps}, 17.8 \pm 1.7 \mathrm{ps}$, and $42.2 \pm 1.6 \mathrm{ps}$ for the cancerous tissue. The recovery in the $\mathrm{ZnPcS}_{4}$ film was also three exponential, with the time constants $1.8 \pm 0.2 \mathrm{ps}$, $13.1 \pm 0.8 \mathrm{ps}$, and $28.4 \pm 1.8 \mathrm{ps}$. These results indicate that the dynamics of the ground state recovery are different for the noncancerous and cancerous tissues, particularly the shortest time constants ( $1.7 \mathrm{ps}$ vs $8.3 \mathrm{ps}$ ).

The recovery of $\mathrm{ZnPcS}_{4}$ bleaching in solution at $674 \mathrm{~nm}$ achieved the best fit, showing three exponential functions with time constants of $11.1 \pm 0.9 \mathrm{ps}, 25.9 \pm 0.5 \mathrm{ps}$, and $307 \pm 79 \mathrm{ps}$. It is important to stress that the dynamics in the solution contains a slow component of 307 ps that has not been observed neither in the tissues nor in the film.

Fig. 9 shows the transient absorption signal $\Delta A(t)$ of $\mathrm{ZnPcS}_{4}$ in the noncancerous and cancerous human breast tissues, $\mathrm{ZnPcS}_{4}$ film and aqueous solution as a function of the time delay when pumped at $633 \mathrm{~nm}$ and probed at $633 \mathrm{~nm}$.

Fig. 9 shows that directly upon excitation with the laser pump pulse at $633 \mathrm{~nm}$, a negative $\Delta A(t)$ signal at $633 \mathrm{~nm}$ was recorded. The negative signal was assigned to the bleaching of the ground state due to the $\operatorname{HOMO}\left(\mathrm{a}_{1 \mathrm{u}}\right) \rightarrow \operatorname{LUMO}\left(\mathrm{e}_{\mathrm{g}}\right)$ transition in the $\mathrm{Q}$ band for $\mathrm{ZnPCS}_{4}$ dimer. The bleaching was instantaneous and limited by the laser pulse width. The recovery of the bleaching at $633 \mathrm{~nm}$ was three exponential and fitted with time constants of $1.1 \pm 0.1 \mathrm{ps}$, $8.3 \pm 0.9 \mathrm{ps}$, and $51.2 \pm 2.6 \mathrm{ps}$ for the noncancerous tissue and $5.6 \pm 0.4 \mathrm{ps}, 16.1 \pm 0.5 \mathrm{ps}$, and $51.7 \pm 3.8 \mathrm{ps}$ for the cancerous tissue. 

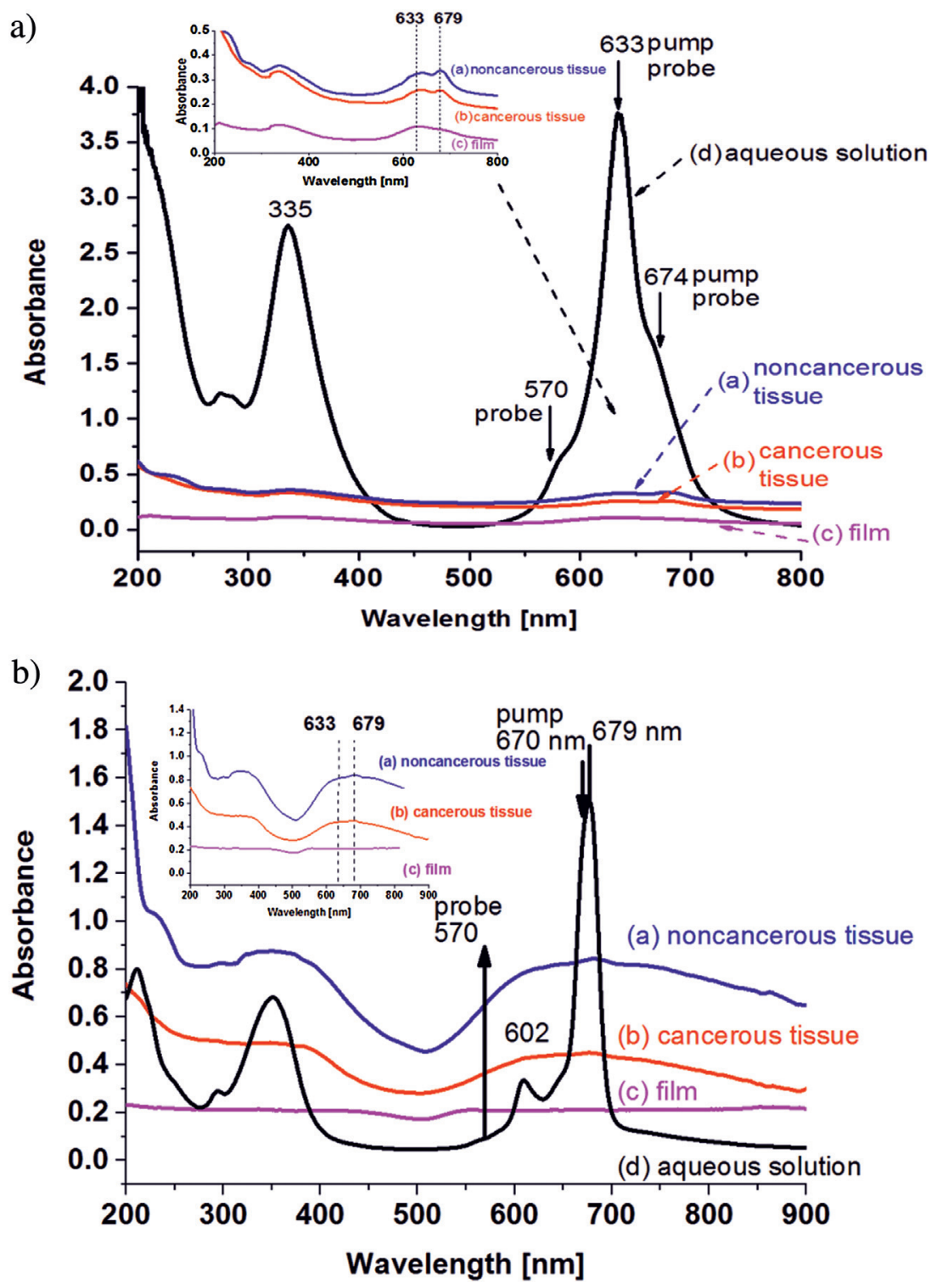

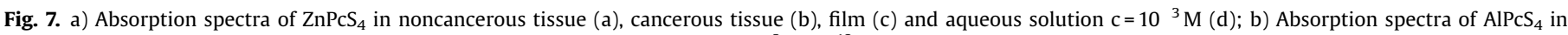
noncancerous tissue (a), cancerous tissue (b), film (c) and aqueous solution $c=10^{3} \mathrm{M}(\mathrm{d})^{18}$.

The recovery in the $\mathrm{ZnPcS}_{4}$ film was also three exponential, with the time constants $1.5 \pm 0.1 \mathrm{fs}, 9.5 \pm 0.6 \mathrm{ps}$, and $19.8 \pm 1.1 \mathrm{ps}$. These results indicate that the dynamics of the ground state $S_{0}$ recovery is different in the noncancerous and the cancerous tissues. The recovery of $\mathrm{ZnPcS}_{4}$ bleaching in solution at $633 \mathrm{~nm}$ when pumped at $633 \mathrm{~nm}$ was three exponential, with the time constants $12.1 \pm 0.7 \mathrm{fs}, 72.8 \pm 14.1 \mathrm{ps}$, and $116 \pm 27 \mathrm{ps}$.

Tables 5 and 6 summarize the characteristic time constants for the dynamics of the ground state by monitoring the $\Delta A(t)$ signal of bleaching recovery for the monomeric species at $674 \mathrm{~nm}$ and the dimer species at $633 \mathrm{~nm}$.

The results presented in Figs. 8 and 9 clearly demonstrate that the photochemical properties of photosensitizers in solutions cannot be directly translated to the biological interfaces. The comparison of the time constants shown in Tables 5 and 6 demonstrates that the mechanisms of energy dissipation for phthalocyanines in bulk solutions and at biological interfaces are dramatically different. First, the dynamics of $\mathrm{ZnPcS}_{4}$ molecules at the biological interface of noncancerous tissue contains a very fast component of around $1 \mathrm{ps}$, which does not exist in bulk solutions.
Second, the dynamics of $\mathrm{ZnPcS}_{4}$ in solution contains the slow component of hundreds of picoseconds, which is not observed at biological interfaces of the tissues. The time constants in solution are consistent with those obtained by Howe et al. [60] for $\mathrm{PcS}_{4}$ and $\mathrm{ZnPcS}_{4}$ in DMSO probed at 720,790 , and $820 \mathrm{~nm}$, but the very fast component of around $1 \mathrm{ps}$ at biological interfaces is a new feature suggesting a different channel of energy dissipation.

To gain further insight into the dynamics of $\mathrm{ZnPcS}_{4}$ we monitored the time evolution of the decay signal in the region of the excited state absorption (ESA) from $S_{1}$ to higher $S_{n}$ states. Fig. 10 shows the ESA transient absorption signal $\Delta A(t)$ of $\mathrm{ZnPcS}_{4}$ in noncancerous and cancerous human breast tissues, in film and in aqueous solution (concentration $10{ }^{3} \mathrm{M}$ ) as a function of the time delay in the full time window up to $10 \mathrm{ps}$ (10a), $100 \mathrm{ps}$ (10b) and $1 \mathrm{~ns}$ (10c), pumped at $674 \mathrm{~nm}$ and probed at $570 \mathrm{~nm}$.

Fig. 10 shows that the instantaneous bleaching of the negative signal of $\mathrm{ZnPcS}_{4}$ in the tissues, film, and water solution at $674 \mathrm{~nm}$ presented in Figs. 8 and 9 is accompanied by a sudden rise at $570 \mathrm{~nm}$, followed by decay. This decay is three exponential and was fitted with time constants of $0.98 \pm 0.1 \mathrm{ps}, 1.6 \pm 0.2 \mathrm{ps}$, 
a)

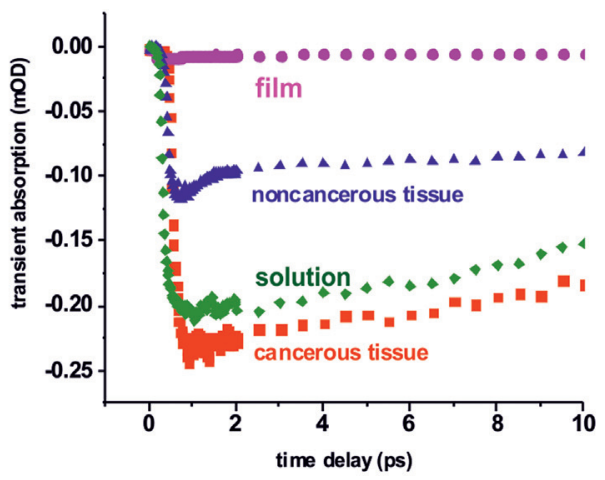

b)

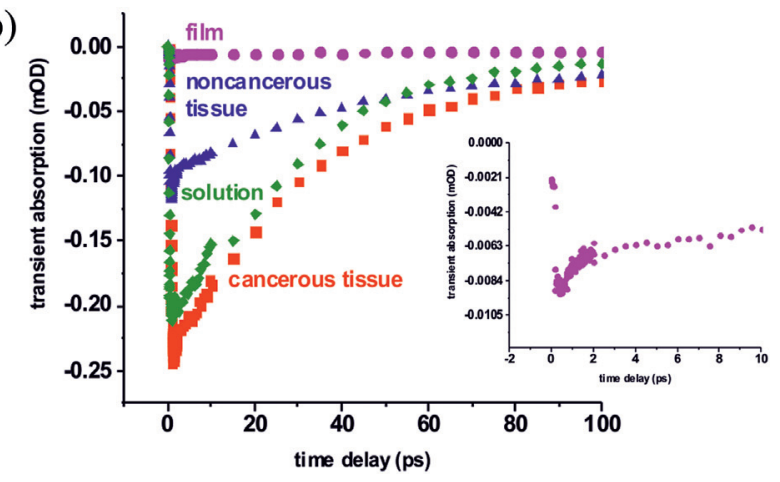

c)

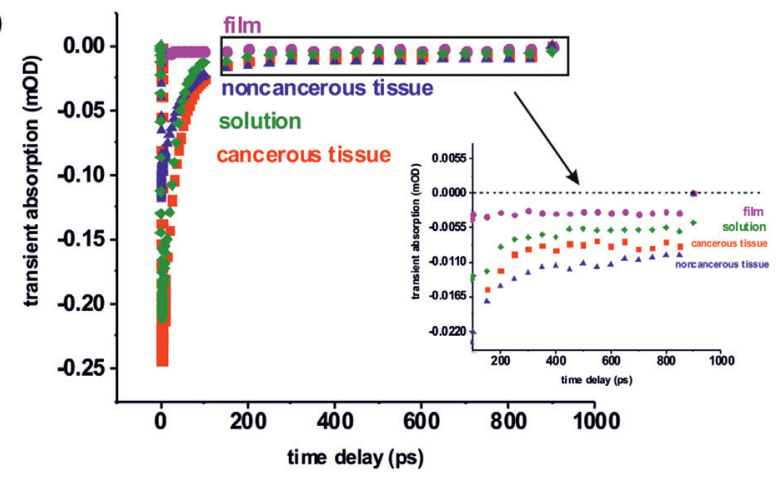

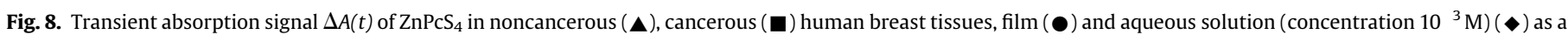
function of the time delay in the full time window up to $10 \mathrm{ps}$ (a), $100 \mathrm{ps}$ (b) and $1 \mathrm{~ns}$ (c), pumped at $674 \mathrm{~nm}$ and .probed at $674 \mathrm{~nm}$.

a)

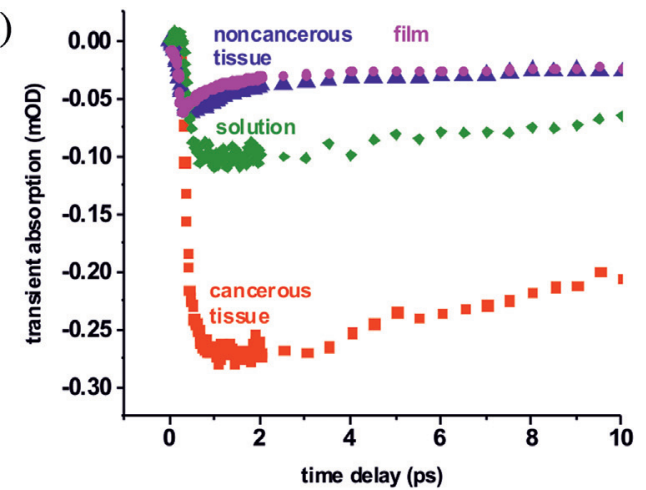

b)

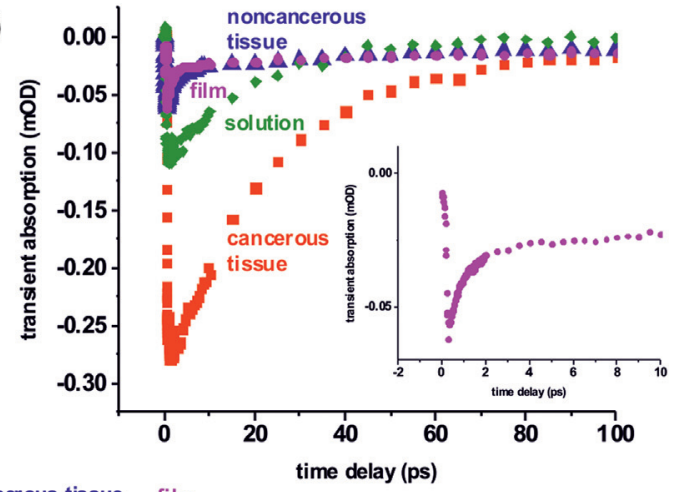

c)

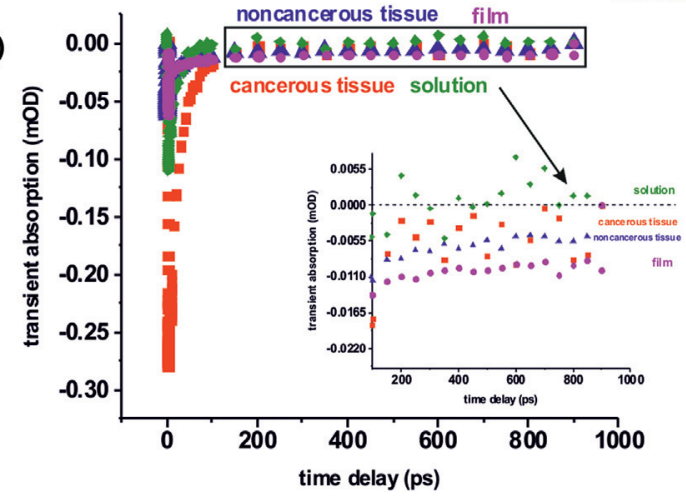

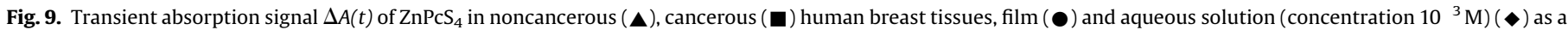
function of the time delay in the full time window up to $10 \mathrm{ps}$ (a), $100 \mathrm{ps}$ (b) and $1 \mathrm{~ns}$ (c), pumped at $633 \mathrm{~nm}$ and probed at $633 \mathrm{~nm}$. 
Table 5

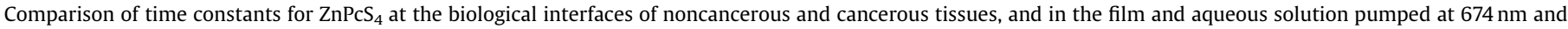
probed at $674 \mathrm{~nm}$.

\begin{tabular}{|c|c|c|c|c|c|c|c|c|}
\hline & \multicolumn{8}{|c|}{ Time constants and amplitudes } \\
\hline & Time constant & Amplitude & Time constant & Amplitude & Time constant & Amplitude & Time constant & Amplitude \\
\hline Noncancerous tissue & $1.7 \pm 0.4$ & $-0.04 \pm 0.008$ & $24.4 \pm 3.1$ & $-0.1 \pm 0.01$ & $59.3 \pm 4.4$ & $-0.1 \pm 0.006$ & & \\
\hline Cancerous tissue & $8.3 \pm 1.2$ & $-0.04 \pm 0.01$ & $17.8 \pm 1.7$ & $-0.11 \pm 0.1$ & $42.2 \pm 1.6$ & $-0.15 \pm 0.1$ & & \\
\hline Film & $1.8 \pm 0.2$ & $-0.005 \pm 2.8 \mathrm{E}-4$ & $13.1 \pm 0.8$ & $-0.005 \pm 6.7 \mathrm{E}-4$ & $28.4 \pm 1.8$ & $-0.01 \pm 5.6 \mathrm{E}-4$ & & \\
\hline Aqueous solution & & & $11.1 \pm 0.9$ & $-0.07 \pm 0.005$ & $25.9 \pm 0.5$ & $-0.27 \pm 0.01$ & $307 \pm 79$ & $-2.92 \pm 0.01$ \\
\hline
\end{tabular}

Table 6

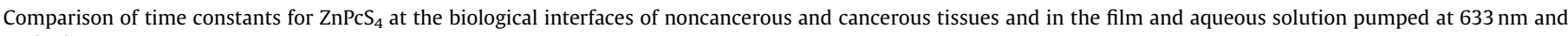
probed at $633 \mathrm{~nm}$.

\begin{tabular}{|c|c|c|c|c|c|c|c|c|}
\hline & \multicolumn{8}{|c|}{ Time constants and amplitudes } \\
\hline & Time constant & Amplitude & Time constant & Amplitude & Time constant & Amplitude & Time constant & Amplitude \\
\hline Noncancerous tissue & $1.1 \pm 0.1$ & & $8.3 \pm 0.9$ & & $51.2 \pm 2.6$ & & & \\
\hline Cancerous tissue & $5.6 \pm 0.4$ & $-0.8 \pm 0.2$ & $16.1 \pm 0.5$ & $-4.4 \pm 0.1$ & $51.7 \pm 3.8$ & $-7.4 \pm 2.4$ & & \\
\hline Film & $1.5 \pm 0.1$ & $-0.06 \pm 0.001$ & $9.5 \pm 0.6$ & $-0.3 \pm 0.003$ & $19.8 \pm 1.1$ & $-0.5 \pm 0.01$ & & \\
\hline Aqueous solution & & & $12.1 \pm 0.7$ & $-1.4 \pm 0.1$ & $72.8 \pm 14.1$ & $-84.1 \pm 0.2$ & $116 \pm 27$ & $-0.05 \pm 0.01$ \\
\hline
\end{tabular}

a)

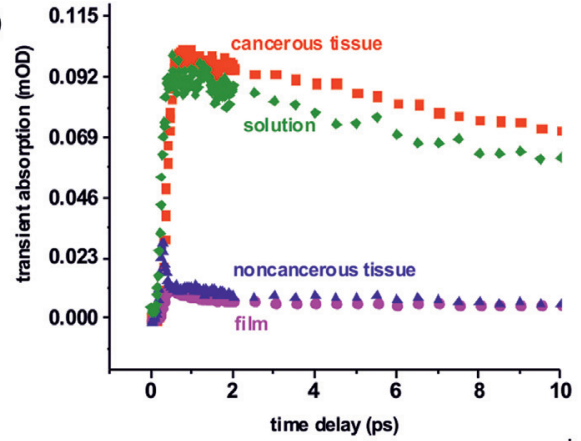

b)

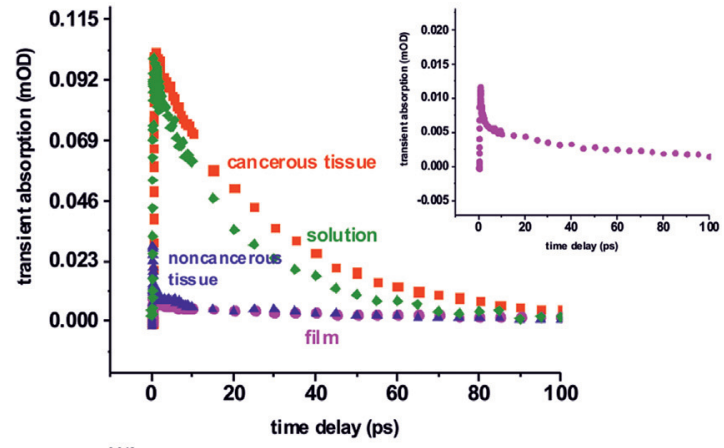

c)

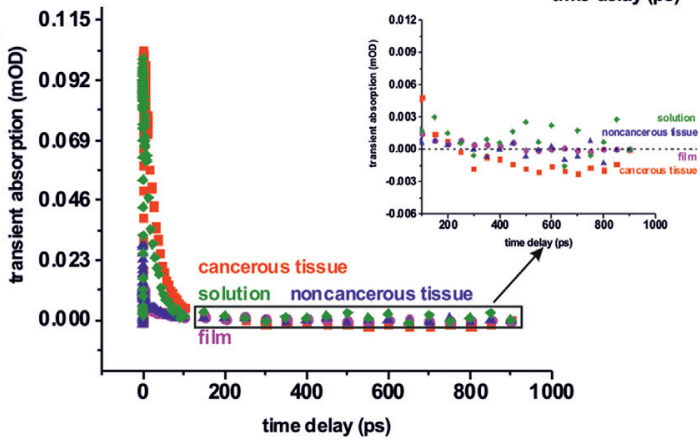

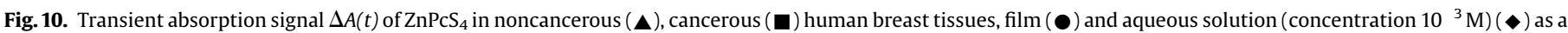
function of the time delay in the full time window up to $10 \mathrm{ps}$ (a), $100 \mathrm{ps}$ (b) and $1 \mathrm{~ns}$ (c), pumped at $674 \mathrm{~nm}$ and probed at $570 \mathrm{~nm}$.

Table 7

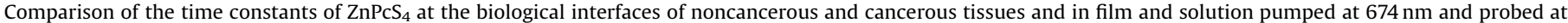
$570 \mathrm{~nm}$.

\begin{tabular}{|c|c|c|c|c|c|c|c|c|}
\hline & \multicolumn{8}{|c|}{ Time constants and amplitudes } \\
\hline & Time constant & Amplitude & Time constant & Amplitude & Time constant & Amplitude & Time constant & Amplitude \\
\hline Noncancerous tissue & $0.98 \pm 0.1$ & $0.04 \pm 0.009$ & $1.6 \pm 0.2$ & $0.03 \pm 0.01$ & $8.9 \pm 0.9$ & $0.01 \pm 0.003$ & & \\
\hline Cancerous tissue & $2.7 \pm 0.2$ & $0.005 \pm 0.001$ & $11.6 \pm 0.5$ & $0.03 \pm 0.002$ & $37.0 \pm 0.6$ & $0.07 \pm 0.001$ & & \\
\hline Film & $1.3 \pm 0.1$ & $0.01 \pm 6.4 \mathrm{E}-4$ & $11.7 \pm 1.5$ & $0.005 \pm 0.001$ & $49.2 \pm 2.5$ & $0.006 \pm 9.1 \mathrm{E}-5$ & & \\
\hline Aqueous solution & $1.3 \pm 0.3$ & $0.03 \pm 0.14$ & & & $21.6 \pm 1.2$ & $0.09 \pm 0.001$ & $108 \pm 16$ & $0.001 \pm 0.001$ \\
\hline
\end{tabular}


$8.9 \pm 0.9 \mathrm{ps}$ for the noncancerous tissue and $2.7 \pm 0.2 \mathrm{ps}$, $11.6 \pm 0.5 \mathrm{ps}, 37.0 \pm 0.6 \mathrm{ps}$ for the cancerous tissue. The results in Fig. 10 clearly demonstrate that the dynamics of $\mathrm{ZnPcS}_{4}$ in the noncancerous tissue are markedly faster than those in the cancerous tissue. The decay of the signal in the $\mathrm{ZnPcS}_{4}$ film was also three exponential, with the time constants $1.3 \pm 0.1 \mathrm{ps}$, $11.7 \pm 1.5 \mathrm{ps}$, and $49.2 \pm 2.5 \mathrm{ps}$. The decay of the signal in the $\mathrm{ZnPcS}_{4}$ aqueous solution was also three exponential, with the time constants $1.3 \pm 0.3 \mathrm{ps}, 21.6 \pm 1.2 \mathrm{ps}$, and $108 \pm 16 \mathrm{ps}$.

Table 7 compares the time constants characterizing the dynamics of the excited state $\mathrm{S}_{1}$ decay of $\mathrm{ZnPcS}_{4}$ at biological interfaces of noncancerous and cancerous tissues and in film and aqueous solution when the monomeric species are excited at $674 \mathrm{~nm}$. The results from Table 7 show that the dynamics of the excited state $S_{1}$ decay for the noncancerous tissue is much faster than that of the cancerous tissue. The dynamics of the noncancer ous tissue is described with three time constants $(0.98 \pm 0.1 \mathrm{ps}$, $1.6 \pm 0.2 \mathrm{ps}, 8.9 \pm 0.9 \mathrm{ps}$ ) and does not contain the slow component observed in the cancerous tissue $(37.0 \pm 0.6 \mathrm{ps})$, film $(49.2 \pm 2.5 \mathrm{ps}$.) and solution $(21.6 \pm 1.2 \mathrm{ps}$, and $108 \pm 16 \mathrm{ps})$.

It is obvious that the distinct dynamics of $\mathrm{ZnPcS}_{4}$ in the noncancerous and the cancerous tissues must be associated with distinct biological environment.

It is worth emphasizing that the dynamics of $\mathrm{ZnPcS}_{4}$ in the ground and the excited state at biological interfaces reveals three different time scales: a) relatively fast component ranging around $1 \mathrm{ps}, \mathrm{b})$ a component of a few picoseconds (8 19) and c) relatively slow component of a few tens of picoseconds (21 $72 \mathrm{ps}$ ). In contrast, the dynamics of $\mathrm{ZnPcS}_{4}$ in solutions exhibits a very slow component in the range of a few hundred picoseconds (108 $307 \mathrm{ps}$ ) which is not observed at the biological interface of the tissue. The slow component was previously reported for many phthalocyanines in solutions (232 ps [15], 2.9 ns [73], 460 [60]).

The longest time constants observed in $\mathrm{ZnPcS}_{4}$ solutions in the range of $108307 \mathrm{ps}$ were assigned to the radiative decay via fluorescence from $S_{1}$ to the ground state.

The most important question that arises after detailed analysis of the energy dissipation channels is why dynamics of photosen sitizer differs so dramatically when studied in solutions and at biological interfaces. One must be noticed that the interactions between the photosensitizer and the tissues seem to be evidently governed by the hydrophobic or hydrophilic properties of the biological interfaces. Fig. 4a shows that the noncancerous human breast tissue is dominated by adipose tissue, embedded ducts and blood vessels. Adipose tissue is hydrophobic as it contains glycerol derivatives (monooleate derivatives [114]). In contrast, the cancerous human breast tissue is dominated by epithelial cells of the ducts, where the cancer occurs (Fig. 4a) The surface of the this type of tissue is hydrophilic [114] and contains a high amount of various proteins. Recently we have also proved that water amount confined in cancerous tissue is markedly higher than that in noncancerous tissue [114]. These features of the tissues can explain why the hydrophilic zinc phthalocyanine $\left(\mathrm{ZnPcS}_{4}\right)$ interacts with the hydrophilic environment of the cancerous breast tissue and exhibits dynamics more similar to the dynamics in aqueous solution than that at the of hydrophobic interface of the noncancerous breast tissue.

\section{Conclusions}

The paper focuses on issues that may open up new horizons and opportunities for understanding the complex spatio temporal interactions of molecules at biological interfaces in realistically crowded environment of the human cells and tissues. Despite of several model studies that have been published so far, no ultrafast dynamics of human tissue has been reported yet. We have found spectacular differences in the dynamics of photosensitizers in the noncancerous and cancerous breast human tissues. So far, the cancer pathology has been derived from the static properties of tissues and the dynamic behavior has not been used to discriminate between the noncancerous and cancerous tissues. In this paper we examined the ground and the excited state dynamics of a photosensitizer $\left(\mathrm{ZnPcS}_{4}\right)$ at the biological interface of the human breast tissue by the pump probe transient absorption femtosecond spectroscopy to obtain information concerning the events occurring in a time scale ranging from femtoseconds to nanoseconds.

First, the results showed that the dynamics of the photosensi tizer was markedly faster in the interfacial regions of the biological tissue than in solutions. Second, the photosensitizer localized in noncancerous tissue dissipates the energy through different pathways than that in cancerous breast tissue. We have shown that the lifetimes characterizing both the ground state $S_{0}$ and the first excited state $S_{1}$ in the interfacial regions of noncancerous tissue are markedly shorter than those in cancerous tissue.

Summarizing our study proved that femtosecond spectroscopy open new capabilities in cancer biology and perfectly fit into the research on functions of biologically active molecules and understanding of light energy dissipation. Our studies have shown that for phthalocyanines as for photosynthesis, the reactions of the photoreceptors rhodopsin, bacteriorhodopsin, photoactive yellow protein, phytochrome, and flavin chromophores femtosecond spectroscopy is a unique technique to study ultrafast processes activated by light collection and molecular mechanisms responsi ble for harvesting the light energy can be used for practical applications in cancer diagnostics.

\section{Acknowledgment}

The project was funded through The National Science Centre Poland Grants: UMO 2012/07/B/ST4/01588 and UMO 2015/19/B/ ST4/01878.

\section{References}

[1] H. Abramczyk, Mechanisms of energy dissipation and ultrafast primary events in photostable systems: H-bond, excess electron, biological photoreceptors, Vib. Spectrosc. 58 (2012) 1-11.

[2] H. Abramczyk, B. Brozek-Pluska, J. Surmacki, J. Musial, R. Kordek, Oncologic photodynamic diagnosis and therapy: confocal Raman/fluorescence imaging of metal phthalocyanines in human breast cancer tissue in vitro, Analyst 139 (2014) 5547-5559.

[3] B. Brozek-Pluska, A. Jarota, J. Jablonska-Gajewicz, R. Kordek, W. Czajkowski, H. Abramczyk, Distribution of phthalocyanines and raman reporters in human cancerous and noncancerous Breast tissue as studied by raman imaging, Technol. Cancer Res. Treat. (TCRT) 4 (2012) 317-331.

[4] S. Roke, J. Schins, M. Müller, M. Bonn, Vibrational spectroscopic investigation of the phase diagram of a biomimetic lipid monolayer, Phys. Rev. Lett. 90 (12) (2003) 128101

[5] B. Brozek-Płuska, A. Jarota, K. Kurczewski, H. Abramczyk, J. Mol. Struct. 924926 (2009) 338-346.

[6] M. Bonn, S. Roke, O. Berg, L.B.F. Juurlink, A. Stamouli, M. Müller, A molecular view of cholesterol-induced condensation in a lipid monolayer, J. Phys. Chem. B 108 (50) (2004) 19083-19085.

[7] P. Hamm, Ultrafast peptide and protein dynamics by vibrational spectroscopy M. Braun, P. Gilch, W. Zinth, Ultrashort laser pulses in biology and medicine Berlin 2008; 77-94 ISBN 978-3-540-73565-6 (P) 978-3-540-73566-3 (E).

[8] P. Hamm, Femtosecond IR pump-Probe spectroscopy of nonlinear energy localization in protein models and model proteins, J. Biol. Phys. 35 (1) (2009) 17-30.

[9] S. Wachsmann-Hogiu, T. Weeks, Th. Huser, Chemical analysis in vivo and in vitro by Raman spectroscopy-from single cells to humans, Curr. Opin. Biotechnol. 20 (1) (2009) 63-73.

[10] Ch. W. Ch. Freudiger, W. Yang, R. Gary, G.R. Holtom, N. Peyghambarian, X.S. Xie, K.Q. Kieu, Stimulated Raman scattering microscopy with a robust fibre laser source, Nat, Photonics 8 (2014) 153-159.

[11] H. Abramczyk, B. Brozek-Pluska, Raman imaging in biochemical and biomedical applications. diagnosis and treatment of Breast cancer, Chem. Rev. 113 (2013) 5766-5781. 
[12] H. Abramczyk, B. Brozek-Pluska, J. Surmacki, J. Jablonska-Gajewicz, R. Kordek, The label-free raman imaging of human Breast cancer, J. Mol. Liq. 164 (2011) $123-131$.

[13] H. Abramczyk, B. Brozek-Pluska, J. Surmacki, J. Jablonska-Gajewicz, R. Kordek, Raman 'optical biopsy' of human breast cancer, Prog. Biophys. Mol. Biol. 108 (2011) 74-81.

[14] H. Abramczyk, J. Surmacki, B. Brozek-Pluska, Z. Morawiec, M. Tazbir, The hallmarks of breast cancer by Raman spectroscopy, J. Mol. Struct. 924-926 (2009) 175-182.

[15] A. Jarota, M. Tondusson, G. Galle, E. Freysz, H. Abramczyk, Ultrafast dynamics of metal complexes of tetrasulphonated phthalocyanines, J. Phys. Chem. A 116 (2012) 4000-4009.

[16] H. Abramczyk, B. Brozek-Płuska, K. Kurczewski, M. Kurczewska, I. Szymczyk, P. Krzyczmonik, T. Błaszczyk, H. Scholl, W. Czajkowski, Femtosecond transient absorption, raman, and electrochemistry studies of tetrasulfonated copper phthalocyanine in water solutions, J. Phys. Chem. A 110 (28) (2006) 8627-8636.

[17] A. Zewail, Femtochemistry-Ultrafast Dynamics of the Chemical Bond, vols. I and II, World Scientific New Jersey, Singapore, 1994.

[18] V. Sundström, Femtobiology, Annu. Rev. Phys. Chem. 59 (2008) 53-77.

[19] Physical Biology From Atoms to Medicine, in: A.H. Zewail (Ed.), Imperial College Press, London, 2008.

[20] H. Abramczyk, B. Brozek-Pluska, M. Tondusson, E. Freysz, Ultrafast dynamics of metal complexes of tetrasulfonated phthalocyanines at biological interfaces: comparison between photochemistry in solutions, films, and noncancerous and cancerous human Breast tissues, J. Phys. Chem C 117 (2013) 4999-5013.

[21] J.S. Nelson, L.H. Liaw, A. Orenstein, W.G. Roberts, M.W. Berns, Mechanism of tumor destruction following photodynamic therapy with hematoporphyrin derivative chlorin, and phthalocyanine, J. Natl. Cancer Inst. 80 (1988) 15991605.

[22] S. Kawauchi, S. Sato, Y. Morimoto, M. Kikuchi, Correlation between oxygen consumption and photobleaching during in vitro photodynamic treatment with ATX-S10-Na(II) using pulsed light excitation: dependence of pulse repetition rate and irradiation time, Photochem. Photobiol. 80 (2004) 216233.

[23] G.M. Peavy, M.K. Klein, H.C. Newman, W. Roberts, M.W. Berns, The use of chloro-aluminum sulfonated pphthalocyanine as a photosensitizer in the treatment of malignant tumors in dogs and cats, Proc. SPIE 1424 (1991) $171-$ 178.

[24] V. Mantareva, V. Kussovski, I. Angelov, D. Wöhrle, R. Dimitrov, E. Popova, S. Dimitrov, Non-aggregated Ga(III)-phthalocyanines in the photodynamic inactivation of planktonic and biofilm cultures of pathogenic microorganisms, Photochem. Photobiol. Sci. 10 (1) (2011) 91-102.

[25] V. Mantareva, I. Angelov, D. Wöhrle, V. Dogandjiska, R. Dimitrov, V. Kussovski, Water-soluble phthalocyanine complexes of $\mathrm{Ga}(\mathrm{III})$ and $\mathrm{In}(\mathrm{III})$ in the photodynamic inactivation of pathogenic fungus, Proc. SPIE 7747 (2010) 774712.

[26] A. Feofanov, T. Grichine, N. Karmakova, E. Kazachkina, R. Pecherskih, V. Luk'yanets, M. Egret-Charlier, P. Vigny, Chelation with metal is not essential for antitumor photodynamic activity of sulfonated phthalocyanines, Photochem. Photobiol. 75 (2002) 527-533.

[27] H. Aragón-Aguilar, E. Ramón-Gallegos, J. Arenas-Huertero, A. ContrerasRamos, A. Cruz-Orea, J.L. Sosa-Sánchez, M. García Miranda, Kinetic of the intraceullular incorporation of new phthalocyanines systhesized in Mexico and its potential as photosensiblizers in the photodynamic therapy, AIP Conf. Proc. 1032 (2008) 299-301.

[28] E.R. Gomes, R.D. Almeida, A.P. Carvalho, C.B. Duarte, Nitric oxide modulates tumor cell death induced by photodynamic therapy through a cGMPdependent mechanism, Photochem. Photobiol. 76 (4) (2002) 423-430.

[29] Q. Peng, J. Moan, Correlation of distribution of sulphonated aluminium phthalocyanines with their photodynamic effect in tumour and skin of mice bearing CaD2 mammary carcinoma, Br. J. Cancer 72 (3) (1995) 565-574.

[30] D. Kessel, M. Castelli, J.J. Reiners Jr., Response to photodynamic therapy versus the Bcl-2 antagonist HA14-1, Photochem. Photobiol. 76 (2002) 314319.

[31] W.S. Strauss, M.H. Gschwend, R. Sailer, H. Schneckenburger, R. Steiner, A. Ruck, Intracellular fluorescence behaviour of meso-tetra(4sulphonatophenyl)porphyrin during photodynamic treatment at various growth phases of cultured cells, Photochem. Photobiol. B 28 (1995) 155-161.

[32] A.M. Garcia, E. Alarcon, M. Muñoz, J.C. Scaiano, A.M. Edwards, E. Lissi Photophysical behaviour and photodynamic activity of zinc phthalocyanines associated to liposomes, Photochem. Photobiol. Sci. 10 (4) (2011) 507-514.

[33] T. Lopez, E. Ortiz, M. Alvarez, J. Navarrete, J.A. Odriozola, F. Martinez-Ortega, E. A. Páez-Mozo, P. Escobar, K.A. Espinoza, I.A. Rivero, Study of the stabilization of zinc phthalocyanine in sol-gel TiO2 for photodynamic therapy applications, Nanomed.: Nanotechnol. Biol. Med. 6 (2010) 777-785.

[34] D.A. Makarov, N.A. Kuznetsova, O.A. Yuzhakova, L.P. Savvina, O.L. Kaliya, E.A. Lukyanets, V. Negrimovskii, M.G. Strakhovskaya, Effects of the degree of substitution on the physicochemical properties and photodynamic activity of zinc and aluminum phthalocyanine polycations, Russ. J. Phys. Chem. A 83 (2009) 1044-1050.

[35] P.T. Chatlani, J. Bedwell, A.J. MacRobert, H. Barr, P.B. Boulos, N. Krasner, D. Phillips, S.G. Bown, Comparison of distribution and photodynamic effects of di-sulfonated and tetra-sulfonated aluminum phthalocyanines in normal rat colon, Photochem. Photobiol. 53 (6) (1991) 745-751.
[36] C. Sheng, B.W. Pogue, E. Wang, J.E. Hutchins, P.J. Hoopes, Assessment of photosensitizer dosimetry and tissue damage assay for photodynamic therapy in advanced-stage tumors, Photochem. Photobiol. 79 (6) (2004) 520 525.

[37] I. Belichenko, N. Morishima, D. Separovic, Caspase-resistant vimentin suppresses apoptosis after photodynamic treatment with a silicon phthalocyanine in jurkat cells, Arch. Biochem. Biophys. 390 (1) (2001) 57-63.

[38] K.N. Halkiotis, L.D. Manolopoulos, N.K. Uzunoglou, D.M. Yova, Drug and light dose dependence of PDT on pancreatic cancer cells In vitro, Proc. SPIE 3423 (1998) 427.

[39] R.R. Allison, V.S. Bagnato, R. Cuenca, G.H. Downie, C.H. Sibata, The future of photodynamic therapy in oncology, Future Oncol. 2 (1) (2006) 53-71.

[40] M.B. Vrouenraets, G.M.W. Visser, G.B. Snow, G.A.M.S. van Dongen, Basic principles, applications in oncology and improved selectivity of photodynamic therapy, Anticancer Res. 23 (2003) 505-522.

[41] B.W. Henderson, T.J. Dougherty, How does the photodymnamic therapy work? Photochem. Photobiol. 55 (1992) 145-157.

[42] R.W. Boyle, D. Dolphin, Structure and biodistribution relationships of photodynamic sensitizers, Photochem. Photobiol. 64 (1996) 469-485.

[43] S.B. Brown, E.A. Brown, I. Walker, The present and future role of photodynamic therapy in cancer treatment, Lancet Oncol. 5 (2004) 497-508.

[44] X.L. Wang, H.W. Wang, K.H. Yuan, F.L. Li, Z. Huang, Combination of photodynamic therapy and immunomodulation for skin diseases-update of clinical aspects, Photochem. Photobiol. Sci. 10 (2011) 704-711.

[45] K. Maduray, A. Karsten, B. Odhav, T.J. Nyokong, In vitro photodynamic effect of aluminum tetrasulfophthalocyanines on melanoma skin cancer and healthy normal skin cells. Photodiagnosis, Photodiagnosis, J. Photochem. Photobiol. B 103 (2) (2011) 98-104.

[46] H. Lui, R.R. Anderson, Photodynamic therapy in dermatology. shedding a different light on skin disease, Arch. Dermatol. 128 (12) (1992) 1631-1636.

[47] T. Stuchinskaya, M. Moreno, M.C. Cook, D. Edwards, D.A. Russell, Targeted photodynamic therapy of Breast cancer cells using antibody-PhthalocyanineGold nanoparticle conjugates, Photochem. Photobiol. Sci. 10 (2011) 822-831.

[48] C.M. Whitacre, T.H. Satoh, L. Xue, N.H. Gordon, N.L. Oleinick, Photodynamic therapy of human Breast cancer xenografts lacking caspase-3, Cancer Lett. 179 (1) (2002) 43-49.

[49] V. Moura, M. Lacerda, P. Figueiredo, M.L. Corvo, M.E.M. Cruz, R. Soares, M.C. Pedroso de Lima, S. Simões, J.N. Moreira, Targeted and intracellular triggered delivery of therapeutics to cancer cells and the tumor microenvironment: impact on the treatment of Breast cancer, Cancer Res. Treat. 133 (1) (2012) $61-73$.

[50] M.J. Witjes, O.C. Speelman, P.G. Nikkels, C.A. Nooren, J.M. Nauta, B. van der Holt, H.L. van Leengoed, W.M. Star, J.L. Roodenburg, In vivo fluorescence kinetics and localisation of aluminum phthalocyanine disulphonate in an autologous tumour model, Br. J. Cancer 73 (5) (1996) 573-580.

[51] M. Austwick, J.H. Woodhams, V. Chalau, C.A. Mosse, C. Eliot, L.B. Lovat, A.J MacRobert, I.J. Bigio, S.G. Bown, Optical measurement of photosensitizer concentration In vivo, JIOHS 4 (2011) 97-111.

[52] J.P. Taquet, C. Frochot, V. Manneville, M. Barberi-Heyob Curr, Phthalocyanines covalently bound to biomolecules for a targeted photodynamic therapy, Med. Chem. 14 (15) (2007) 1673-1687.

[53] K. Tokumaru, in: H. Shirai, N. Kobayashi (Eds.), Phthalocyanines, IPC, Tokyo, 1997.

[54] D.R. Prasad, G. Ferraudi, Photochemistry of transition-metal phthalocyanines. monophotonic and sequential biphotonic photochemical processes of copper(II) tetrakis(N-octadecylsulfamoyl)phthalocyanine in nonaqueous, Inorg. Chem. 21 (1982) 2967-2971.

[55] S. Muralidharan, G. Ferraudi, Sequential biphotonic processes in rhodium(III) phthalocyanines, J. Phys. Chem. 87 (1983) 4877-4881.

[56] G. Ferraudi, S. Muralidharan, Photochemistry of transition-metal phthalocyanines. analysis of the photochemical and photophysical properties of the acido(phthalocyaninato)rhodium(III) complexes, Inorg. Chem. 22 (1983) 1369-1374.

[57] Y. Kaneko, T. Arai, H. Sakarugi, K. Tokumaru, C. Pac, Effect of excitation wavelength on photoreduction of metal-free and copper(II) 1,4,8,11,15,18,22,25-octabutoxyphthalocyanines with triethanolamine, J. Photochem. Photobiol. A 97 (1996) 155-162.

[58] Y. Kaneko, Y. Nishimura, T. Arai, H. Sakuragi, K. Tokumaru, D. Matsunaga, U.V. Light, Red light chemistry of metallophthalocyanine: wavelength-dependent photochemical reduction of tetrasodium salts of $\mathrm{Zn}(\mathrm{II})$ and $\mathrm{Cu}(\mathrm{II})$ tetrasulphonatophthalocyanines with amines, J. Photochem. Photobiol. A 89 (1995) 37-44.

[59] Y. Kaneko, Y. Nishimura, N. Takane, T. Arai, H. Sakuragi, K. Tokumaru, N. Kobayashi, D. Matsunaga, Violet emission observed from phthalocyanines, J. Photochem. Photobiol. A 106 (1997) 177-183.

[60] I. Howe, J.Z. Zhang, Ultrafast studies of excited-state dynamics of phthalocyanine and zinc phthalocyanine tetrasulfonate in solution, J. Phys. Chem. A 101 (1997) 3207-3213.

[61] I. Ruckmann, A. Zeug, R. Herter, B. Roder, On the influence of higher excited states on the ISC quantum yield of octa-aL-alkyloxy-substituted $\mathrm{Zn}$ phthalocyanine molecules studied by nonlinear absorption, Photochem. Photobiol. 66 (1997) 576-584.

[62] D. Chahraoui, P. Valet, J. Kossanyi, Fluorescence of phthalocyanines: emission from an upper excited state, Res. Chem. Intermed. 17 (1992) 219-232. 
[63] N. Kobayashi, T. Ashida, T. Osa, Synthesis, spectroscopy, electrochemistry, and spectroelectrochemistry of a zinc phthalocyanine with D2h symmetry, Chem. Lett. 10 (1992) 2031.

[64] N. Kobayashi, A.B.P. Lever, Cation or solvent-induced supermolecular phthalocyanine formation: crown ether substituted phthalocyanines, J. Am. Chem. Soc. 109 (1987) 7433-7441.

[65] N. Kobayashi, H. Lam, W.A. Nevin, C.C. Leznoff, T. Koyama, A. Monden, H. Shirai, Spectroscopy, electrochemistry, spectroelectrochemistry, LangmuirBlodgett film formation, and molecular orbital calculations of planar binuclear phthalocyanines, J. Am. Chem. Soc. 116 (1994) 879-890.

[66] N. Kobayashi, M. Togashi, T. Osa, K. Ishii, S. Yamauchi, H. Hino, Low symmetrical phthalocyanine analogues substituted with three crown ether voids and their cation-Induced supermolecules, J. Am. Chem. Soc. 118 (1996) 1073-1085.

[67] Q. Zhong, Z. Wang, Y. Liu, Q. Zhu, F. Kong, The ultrafast intramolecular dynamics of phthalocyanine and porphyrin derivatives, J. Chem. Phys. 105 (1996) 5377-5379.

[68] S.J. Strickler, R.A. Berg, Relationship between absorption intensity and fluorescence lifetime of molecules, J. Chem. Phys. 37 (1962) 814-822.

[69] A. Gilbert, J. Baggott, Essentials of Molecular Photochemistry, Blackwell, Oxford, 1991.

[70] I. Rosenthal, C.M. Krishna, P. Riesz, E. Ben-Hur, The role of molecular oxygen in the photodynamic effect of phthalocyanines, Radiat. Res. 107 (1989) 136142.

[71] K.J. Tokumaru, Photochemical and photophysical behaviour of porphyrins and phthalocyanines irradiated with violet or ultraviolet light, J. Porphyrins Phthalocyanines 5 (2001) 77-86.

[72] S. FitzGerald, C. Farren, C.F. Stanley, A. Beeby, M.R. Bryce, Protonation of tetrasulfonated zinc phthalocyanine in aqueous acetonitrile solution, Photochem. Photobiol. Sci. 1 (8) (2002) 581-587.

[73] J. Savolainen, D. van der Linden, N. Dijkhuizen, J.L. Herek, Characterizing the functional dynamics of zinc phthalocyanine from femtoseconds to nanoseconds, Photochem. Photobiol. A 196 (2008) 99-105.

[74] Z.Z. Ho, N. Peyghambarian, Femtosecond dynamics in organic thin films of fluoro-Aluminium phthalocyanine, Chem. Phys. Lett. 148 (1988) 107-111.

[75] S.V. Rao, D.N. Rao, Excited state dynamics in phthalocyanines studied using degenerate four wave mixing with incoherent light, J. Porphyrins Phthalocyanines 6 (2002) 233-237.

[76] Y. Hosokawa, M. Yashiro, T. Asahi, H. Fukumura, H. Masuhara, Femtosecond laser ablation dynamics of amorphous film of a substituted $\mathrm{Cu}-$ phthalocyanine, Appl. Surf. Sci. 154-155 (2000) 192-195.

[77] M. Lam, Y. Lee, M. Deng, A.H. Hsia, K.A. Merrissey, Ch. Yan, K. Azzizudin, N. Oleinick, T. McCormick, K. Cooper, E. Baron, Photodynamic therapy with the silicon phthalocyanine pc 4 induces apoptosis in mycosis fungoides and sezary syndrome, Adv. Hematol. (2010) (article ID 896161).

[78] N.S. Hush, I.S. Woolsey, The electronic absorption spectra of phthalocyanine monomers and dimers, Mol. Phys. 21 (1971) 465-474.

[79] N. Kobayashi, A.B.P. Lever, Cation or solvent-induced supermolecular phthalocyanine formation: crown ether substituted phthalocyanines, J. Am. Chem. Soc. 109 (1987) 7433-7441.

[80] A.R. Kane, J.F. Sullivan, D.H. Kenny, M.E. Kenney, The nuclear magnetic resonance spectra and the electronic spectra of some silicon and germanium phthalocyanines, Inorg. Chem. 9 (1987) 1445-1448.

[81] S. Dhami, J.J. Cosa, S.M. Bishop, D. Phillips, Photophysical characterization of sulfonated aluminum phthalocyanines in a cationic reversed micellar system, Langmuir 12 (1996) 293-300.

[82] R.B. Ostler, Ph.D. Thesis, University of London, 2016, pp. 1997.

[83] A.W. Snow, in: K.M. Kadish, K.M. Smith, R. Guilard (Eds.), The Porphyrin Handbook, vol. 17, Academic Elsevier, 2003, pp. 129-176.

[84] F. Dumoulin, M. Durmus, V. Ahsen, T. Nyokong, Synthetic pathways to watersoluble phthalocyanines and close analogs, Coord. Chem. Rev. 254 (2010) 2792-2847J.

[85] Morgan, A.R. Oseroff, Mitochondria-based photodynamic anti-cancer therapy, Adv. Drug Deliv. Rev. 49 (2001) 71-86.

[86] J. Zawacka-Pankau, J. Krachulec, I. Grulkowski, K.P. Bielawski, G. Selivanova, The p53-mediated cytotoxicity of photodynamic therapy of cancer, Toxicol Appl. Pharmacol. 232 (2008) 487-497.

[87] J. Piette, C. Volanti, A. Vantieghem, J.Y. Matroule, Y. Habraken, P. Agostinis, Cell death and growth arrest in response to photodynamic therapy with membrane bound photosensitizers, Biochem. Pharmacol. 66 (2003) 16511659.

[88] R.K. Jain, Delivery of molecular and cellular medicine to solid, Tumors Adv. Drug Deliv. Rev. 46 (2001) 149-168.

[89] D.J. Ball, S. Mayhew, S.R. Wood, J. Griffiths, D.I. Vernon, S.B. Brown, Comparative study of the cellular uptake and photodynamic efficacy of three novel zinc phthalocyanines of differing charge, Photochem. Photobiol. 69 (3) (1999) 390-396.

[90] A.A. Pashkovskaya, I.V. Perevoshchikova, V.E. Maizlish, G.P. Shaposhnikov, E A. Kotova, Y.N. Antonenko, Interaction of tetrasubstituted cationic aluminum phthalocyanine with artificial and natural membranes, Biochemistry (Mosc). 74 (9) (2009) 1021-1026.

[91] T.I. Rokitskaya, M. Block, Y.N. Antonenko, E.A. Kotova, P. Pohl, Photosensitizer binding to lipid bilayers as a precondition for the photoinactivation of membrane channels, Biophys. J. 78 (5) (2000) 2572-2580.
[92] H. Yaku, T. Murashima, D. Miyoshi, N. Sugimoto, Anionic phthalocyanines targeting G-quadruplexes and inhibiting telomerase activity in the presence of excessive DNA duplexes, Chem. Commun. 46 (2010) 5740-5742.

[93] E. Crescenzi, L. Varriale, M. Iovino, A. Chiaviello, B.M. Veneziani, G. Palumbo, Photodynamic therapy with indocyanine green complements and enhances low-dose cisplatin cytotoxicity in MCF-7 breast cancer cells, Mol. Cancer Ther. 3 (2004) 537-544.

[94] E. Ruoslahti, Synthesis of a new water-soluble octa-cationic phthalocyanine derivative for PDT, Nat. Rev. Cancer 2 (2002) 83-90.

[95] Q. Peng, J. Moan, J.M. Nesland, Targeting of bioactive compounds to mitochondria, Ultrastruct. Pathol. 20 (1996) 109-129.

[96] M.P. De Filippis, D. Dei, L. Fantetti, G. Roncucci, Photodynamic therapy, Tetrahedron Lett. 41 (2000) 9143-9147.

[97] M.P. Murphy, Studies expand potential uses of photodynamic therapy, JNCI J. Natl. Cancer Inst. 94 (23) (2002) 1740-1742.

[98] T.J. Dougherty, Ch. J. Gomer, B.W. Henderson, G. Jori, D. Kessel, M. Korbelik, J. Moan, Q. Peng, JNCI Cancer Spectr. 90 (1998) 889-905.

[99] G. McBride, Studies expand potential uses of photodynamic therapy, JNCI Cancer Spectr. 94 (2002) 1740-1742.

[100] J. Locklin, K. Shinbo, K. Onishi, F. Kaneko, Z. Bao, R.C. Advincula, Ambipolar organic thin film transistor-like behavior of cationic and anionic phthalocyanines fabricated using layer-by-layer deposition from aqueous solution, Chem. Mater. 15 (7) (2003) 1404-1412.

[101] G. Ma, J. He, C. Kang, S. Tang, Excited state dynamics studies of iron(III) phthalocyanine using femtosecond Pump-Probe techniques, Chem. Phys. Lett. 370 (2003) 293-299.

[102] S. Dayal, R. Królicki, Y. Lou, X. Qiu, J.C. Berlin, M.E. Kenney, C. Burda, Femtosecond time-resolved energy transfer from CdSe nanoparticles to phthalocyanines, Appl. Phys. B 84 (2006) 309-315.

[103] Y. Liu, K. Shigara, M. Hara, A. Yamada, Electrochemistry and electrochromic behavior of Langmuir-Blodgett films of octakis-substituted rare-earth metal diphthalocyanines, J. Am. Chem. Soc. 113 (1992) 440-443.

[104] A.V. Nikolaitchik, O. Korth, M.A.J. Rodgers, Crown ether substituted monomeric and cofacial dimeric metallophthalocyanines. 1. Photophysical studies of the free base zinc(II), and copper(II) variants, J. Phys. Chem. A 103 (1999) 7587-7596.

[105] A.A. Rosenkranz, D.A. Jans, A.S. Sobolev, Targeted intracellular delivery of photosensitizers to enhance photodynamic efficiency, Cell Biol. 78 (2000) $452-464$.

[106] J. Griffiths, J. Schofield, M. Wainwright, S.B. Brown, Some observations on the synthesis of polysubstituted zinc phthalocyanine sensitisers for photodynamic therapy, Dyes Pigm. 33 (1997) 65-78.

[107] Sigma-Aldrich Mayers Hämatoxylin-Lösung Verfahrens Nr. MHS AR-MED Ltd. 2003.

[108] J. Surmacki, B. Brozek-Pluska, R. Kordek, H. Abramczyk, The lipid-reactive oxygen species phenotype of breast cancer. Raman spectroscopy and mapping, PCA and PLSDA for invasive ductal carcinoma and invasive lobular carcinoma. Molecular tumorigenic mechanisms beyond Warburg effect, Analyst 10 (2015) 2121-2133.

[109] B. Brozek-Pluska, M. Kopec, I. Niedzwiecka, A. Morawiec-Sztandera, Labelfree determination of lipids composition and secondary proteins structure of human salivary noncancerous and cancerous tissues by Raman microspectroscopy, Analyst 140 (2015) 2107-2113.

[110] B. Brozek-Pluska, M. Kopec, J. Surmacki, H. Abramczyk, Raman microspectroscopy of the noncancerous and the cancerous human breast tissues. Identification and phase transitions of linoleic and oleic acids by Raman spectroscopy and Raman low-temperature studies, Analyst 140 (2015) 2134-2143.

[111] H. Abramczyk, B. Brozek-Pluska, J. Surmacki, J. Musial, R. Kordek, Oncologic photodynamic diagnosis and therapy: confocal Raman/fluorescence imaging of metal phthalocyanines in human breast cancer tissue in vitro, Analyst 139 (21) (2014) 5547-5559.

[112] B. Brozek-Pluska, J. Musial, R. Kordek, E. Bailo, Th. Dieing, H. Abramczyk, Raman spectroscopy and imaging: applications in human breast cancer diagnosis, Analyst 137 (16) (2012) 3773-3780.

[113] R. Lüllmann-Rauch, Taschenlehrbuch Histologie Georg Thieme, Verlag, Stuttgart, 2006.

[114] B. Brozek-Pluska, J. Jablonska-Gajewicz, R. Kordek, H. Abramczyk, Phase transitions in oleic acid and in human breast tissue as studied by Raman spectroscopy and Raman imaging, J. Med. Chem. 54 (2011) 33863392.

[115] I. Notingher, Raman spectroscopy cell-based biosensors, Sensors 7 (2007) 1343-1358.

[116] F.S. Parker, Applications of Raman and Resonace Raman Spectroscopy in Biochemistry, Plenum Press, New York, 1983.

[117] S. Verier, I. Nothinger, J.M. Polak, L.L. Hench, In situ monitoring of cell death using Raman microspectroscopy, Biopolymers 74 (2004) $158-162$.

[118] A. Mahadevan-Jansen, M.F. Mitchell, N. Ramanujam, A. Malpica, S. Thomsen, U. Utzinger, Near-infrared raman spectroscopy for In vitro detection of cervical precancers, Photochem. Photobiol. 68 (1998) 123-132.

[119] P. Lasch, W. Haensch, D. Naumann, M. Diem, Imaging of colorectal adenocarcinoma using FT-IR microspectroscopy and cluster analysis, Biochim. Biophys. Acta 1688 (2004) 176-186. 
[120] M. Quinn, A. Jirasek, J. Lum, X. Duan, A.G. Brolo, Variability in raman spectra of single human tumor cells cultured in vitro: correlation with cell cycle and culture confluency, Appl. Spectrosc. 64 (2010) 871-887.

[121] H. Abramczyk, B. Brozek-Pluska, J. Surmacki, J. Jablonska-Gajewicz, R. Kordek, JBC 2 (2011) 158-169.

[122] H. Abramczyk, B. Brozek-Pluska, J. Surmacki, J. Jablonska-Gajewicz, R. Kordek, Hydrogen bonds of interfacial water in human Breast cancer tissue compared to lipid and DNA interfaces, J. Mol. Liq. 164 (2011) 123-131.

[123] J. Kneipp, J. Schut, T.B. Kliffen, M. Menke-Pluijmers, G. Puppels, Characterization of breast duct epithelia: a Raman spectroscopic study, Vib. Spectrosc. 32 (2003) 67-74.

[124] C.C. Leznoff, A.B.P. Laver, Phthalocyanines, Wiley-VCH, 1989.

[125] M. Kasha, Energy transfer mechanisms and the molecular exciton model for molecular aggregates, Radiat. Res. 20 (1963) 55-71.

[126] J.P. Zelina, Ch K. Njue, J.F. Rusling, G.N. Kamau, M. Masila, J. Kibugu, Influence of surfactant-based microheterogeneous fluids on aggregation of copper phthalocyanine tetrasulfonate, J. Porphyrins Phthalocyanins 3 (1999) 188-195.
[127] M.D.F.S. Barbosa, F.J. Barrat, V.T. Tchernev, Q.A. Nguyen, V.S. Mishra, S.D. Colman, E. Pastural, R. Dufourcq-Lagelouse, A. Fischer, R.F. Holcombe, M.R. Wallace, S.J. Brandt, G. de Saint Basile, S.F. Kingsi'mora, Identification of mutations in two major mRNA isoforms of the Chediak-Higashi syndrome gene in human and mouse, Hum. Mol. Genet. 6 (1997) 1091-1098.

[128] T. Renoit, J.M. Hayes, G.J. Small, M.C. Zerner, Q-band splitting and relaxation of aluminum phthalocyanine tetrasulfonate, Chem. Phys. Lett. 299 (1999) $410-416$.

[129] J.R. Lakowicz, Principles of Fluorescence Spectroscopy, 3rd ed., Kluwer Academic/Plenum Publishers, New York, London, Moscow, Dordrecht, 1999.

[130] H. Satzger, D. Townsend, M.Z. Zgierski, S. Patchkovskii, U.A. Stolow, Reassignment of the low lying cationic states in gas phase adenine and 9methyl adenine, PNAS USA 103 (2006) 10196-10201.

[131] M.F. Rode, A.L. Sobolewski, Photophysics of inter-and intra-molecularly hydrogen-bonded systems: computational studies on the pyrrole-pyridine complex and 2 (2'-pyridyl) pyrrole, Chem. Phys. 347 (2008) 413-421. 